\title{
Monthly mean climatology of the prevailing winds and tides in the Arctic mesosphere/lower thermosphere
}

\author{
Y. I. Portnyagin ${ }^{1}$, T. V. Solovjova ${ }^{1}$, N. A. Makarov ${ }^{1}$, E. G. Merzlyakov ${ }^{1}$, A. H. Manson ${ }^{2}$, C. E. Meek ${ }^{2}$, W. Hocking ${ }^{3}$, \\ N. Mitchell ${ }^{4}$, D. Pancheva ${ }^{4}$, P. Hoffmann ${ }^{5}$, W. Singer ${ }^{5}$, Y. Murayama ${ }^{6}$, K. Igarashi ${ }^{6}$, J. M. Forbes ${ }^{7}$, S. Palo ${ }^{7}$, C. Hall ${ }^{8}$, \\ and S. Nozawa ${ }^{9}$ \\ ${ }^{1}$ Institute for Experimental Meteorology, Obninsk, Russia \\ ${ }^{2}$ ISAS, University of Saskatchewan, Saskatoon, Canada \\ ${ }^{3}$ University of Western Ontario, London, Canada \\ ${ }^{4}$ University of Wales, Aberystwyth, UK \\ ${ }^{5}$ Institute of Atmospheric Physics, Kühlungsborn, Germany \\ ${ }^{6}$ Communication Research Laboratory, Tokyo, Japan \\ ${ }^{7}$ University of Colorado, Boulder, USA \\ ${ }^{8}$ University of Troms $\varnothing$, Norway \\ ${ }^{9}$ University of Nagoya, Japan
}

Received: 11 September 2003 - Revised: 1 June 2004 - Accepted: 21 June 2004 - Published: 3 November 2004

\begin{abstract}
The Arctic MLT wind regime parameters measured at the ground-based network of MF and meteor radar stations (Andenes $69^{\circ} \mathrm{N}$, Troms $\varnothing 70^{\circ} \mathrm{N}$, Esrange $68^{\circ} \mathrm{N}$, Dixon $73.5^{\circ} \mathrm{N}$, Poker Flat $65^{\circ} \mathrm{N}$ and Resolute Bay $75^{\circ} \mathrm{N}$ ) are discussed and compared with those observed in the midlatitudes. The network of the ground-based MF and meteor radars for measuring winds in the Arctic upper mesosphere and lower thermosphere provides an excellent opportunity for study of the main global dynamical structures in this height region and their dependence from longitude. Preliminary estimates of the differences between the measured winds and tides from the different radar types, situated 125$273 \mathrm{~km}$ apart (Troms $\varnothing$, Andenes and Esrange), are provided. Despite some differences arising from using different types of radars it is possible to study the dynamical wind structures. It is revealed that most of the observed dynamical structures are persistent from year to year, thus permitting the analysis of the Arctic MLT dynamics in a climatological sense. The seasonal behaviour of the zonally averaged wind parameters is, to some extent, similar to that observed at the moderate latitudes. However, the strength of the winds (except the prevailing meridional wind and the diurnal tide amplitudes) in the Arctic MLT region is, in general, less than that detected at the moderate latitudes, decreasing toward the pole. There are also some features in the vertical structure and seasonal variations of the Arctic MLT winds which are different from the expectations of the well-known empirical wind models CIRA-86 and HWM-93. The tidal phases show a very definite longitudinal dependence that permits the determination of the corresponding zonal wave numbers. It is shown that
\end{abstract}

Correspondence to: Y. I. Portnyagin

(yportgin@typhoon.obninsk.org) the migrating tides play an important role in the dynamics of the Arctic MLT region. However, there are clear indications with the presence in some months of non-migrating tidal modes of significant appreciable amplitude.

Key words. Meteorology and atmospheric dynamics (middle atmosphere dynamics, climatology; waves and tides, instruments and techniques)

\section{Introduction}

Study of the main dynamical processes in the Arctic mesosphere/lower thermosphere (MLT) region is very important for comprehensive understanding and modelling of the global circulation of the Earth's atmosphere. While there have been regular MLT wind measurements in the middle and low latitudes and even in Antarctic, there is a dearth of wind measurements in the MLT from the Arctic region. There exist several works to provide us with a glimpse of the MLT dynamics above about $65^{\circ}$ of north latitude. The first MLT meteor radar wind measurements in the Arctic were carried out at the Heiss Island $\left(80.5^{\circ} \mathrm{N}, 58^{\circ} \mathrm{E}\right)$ for the period 1965-1985 (see Lysenko et al., 1969, 1972, 1979; Iljichev et al., 1974; Portnyagin et al., 1993a, 1993b; Fraser et al., 1995). The MLT wind measurements in the Arctic were also carried out between $1967-1968$ at College $\left(65^{\circ} \mathrm{N}, 148^{\circ} \mathrm{W}\right.$;

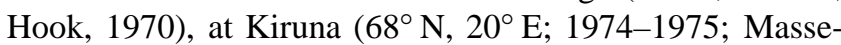
beuf et al., 1979; Manson et al., 1985, 1987), at Poker Flat $\left(65^{\circ} \mathrm{N}, 147^{\circ} \mathrm{W}\right.$; $1980-1984$; Avery et al., 1989; Manson et al., 1985, 1987), and at Troms $\varnothing\left(70^{\circ} \mathrm{N}, 19^{\circ} \mathrm{E}\right.$; Manson et al., 1985, 1987, 1991, 2002a). Avery et al. (1989) summarized what was known about the high-latitude MLT wind 
Table 1.

\begin{tabular}{llccc}
\hline Station & Location & Observ. period & Equipment & Height limits \\
\hline Heiss Island & $80.5^{\circ} \mathrm{N}, 58^{\circ} \mathrm{E}$ & $1965-1981$ & MR & $88-90$ \\
Resolute Bay & $75^{\circ} \mathrm{N}, 95^{\circ} \mathrm{W}$ & $1997-2001$ & VHF (meteors) & $82-98$ \\
Dixon isl. & $72.5^{\circ} \mathrm{N}, 80.5^{\circ} \mathrm{E}$ & $1999-2001$ & MR & $88-90$ \\
Troms $\varnothing$ & $70^{\circ} \mathrm{N}, 19^{\circ} \mathrm{E}$ & $1994-2000$ & MF & $70-97$ \\
Andenes & $69^{\circ} \mathrm{N}, 19^{\circ} \mathrm{E}$ & $1999-2000$ & MF & $70-98$ \\
Esrange & $68^{\circ} \mathrm{N}, 21^{\circ} \mathrm{E}$ & $1999-2001$ & MR & $81-97$ \\
Kiruna & $68^{\circ} \mathrm{N}, 20^{\circ} \mathrm{E}$ & $1974-1975$ & MR (zonal comp.) & $70-100$ \\
Poker Flat & $65^{\circ} \mathrm{N}, 147^{\circ} \mathrm{W}$ & $1998-2000$ & MF & $60-108$ \\
Point Barrow & $72^{\circ} \mathrm{N}, 157^{\circ} \mathrm{W}$ & 2002 & MR & $82-98$ \\
Svalbard & $78^{\circ} \mathrm{N}, 18^{\circ} \mathrm{E}$ & 2002 & MR & $81-97$ \\
\hline
\end{tabular}

climatology. Further discussion of MLT dynamics in the Arctic was provided by Manson et al. (1991) and Portnyagin et al. (1993a, b). It was shown that the main features of the MLT dynamics in the polar region have some similarities with, as well as significant differences from, those observed in the mid-latitude MLT region. While these measurements of the Arctic MLT winds have provided a significant enhancement to our basic understanding of the polar MLT dynamics, there is a consensus that much remains to be learned. In particular, there is a serious lack of coordinated simultaneous measurements from a network of radars in the Arctic, which are well distributed over the longitudes. Recently (mainly since 1999) continuous simultaneous Arctic MLT wind radar measurements were begun at several stations: Andenes $69^{\circ} \mathrm{N}$, Esrange $68^{\circ} \mathrm{N}$, Dixon $73.5^{\circ} \mathrm{N}$, Poker Flat $65^{\circ} \mathrm{N}$ and Resolute Bay $75^{\circ} \mathrm{N}$. The Troms $\varnothing \mathrm{MF}$ radar $\left(70^{\circ} \mathrm{N}\right)$ continues to operate in an upgraded mode. Data from there and from other radars for the years 1999 and 2000 are also now available for intercomparisons and studies of the dynamics and wave motions around the " $70^{\circ} \mathrm{N}$ " longitudinal chain; this has also been called the DATAR project (Dynamics And Temperatures from the Arctic MLT Region). The preliminary results of the meteor radar wind measurements at Dixon have recently been published by Merzlyakov et al. (2001, 2003). Detailed comparisons of the winds and tides from the "Scandinavian Triangle" (Andenes, Troms $\varnothing$, Esrange) of radars have been published by Manson et al., 2004a; as well as results from the new Poker Flat radar (Kishore et al., 2002) and their comparison with the results from Davis in Antarctica (Kishore et al., 2003).

There are also two additional meteor radars at Point Barrow $72^{\circ} \mathrm{N}$ and Svalbard $78^{\circ} \mathrm{N}$, which recently commenced their wind measurements in the Arctic (Troms $\varnothing$-Svalbard; Hall et al., 2003). It is worthwhile to note that at high latitudes the space-based (UARS) MLT wind data have not been measured due to specific UARS orbits. The high-latitude wind measurement results from the new satellite "TIMED" are not yet available for detailed intercomparisons. In this pa- per the main regularities of the seasonal course of the Arctic MLT wind regime parameters measured at the ground-based network of stations are discussed and compared with those observed in the mid-latitudes.

\section{Instrumentation and data sets}

\section{Radar network in the Arctic}

In Table 1 the information about the DATAR radar network in the Arctic is given.

Because we are interested in the climatic characteristics of the Arctic MLR wind regime, we have added to this list the stations operated in the interval 1970-1980, namely Heiss Island and Kiruna, while the data from Svalbard and Point Barrow were not available during the preparation of this paper.

The radar at Resolute Bay is entirely VHF (Hocking et al., 2001b). It has 4 main modes: tropospheric (Doppler), mesospheric, ionospheric, and meteor-detection. The winds presented here were from the meteor mode. The peak TX power is $12 \mathrm{~kW}$, the duty cycle is $5 \%$, and it uses Barker pulses with 5 elements, each sub-element being $2 \mathrm{~km}$ in length. The TX polar diagram is similar to that described by Hocking and Thayaparan (1997), and it uses 4 receiving antennas and interferometry to locate meteors. The frequency is $51.5 \mathrm{MHz}$. Alternation between the meteor and tropospheric modes, on about a 5-min cycle, is used most of the time. The average height is estimated as $86-88 \mathrm{~km}$, with changes of about $2 \mathrm{~km}$ daily and seasonally.

\section{Dixon $\left(73.5^{\circ} \mathrm{N}, \mathbf{8 0 . 5}^{\circ} \mathrm{E}\right)$}

The Dixon Cobra-1 meteor radar system is a quasi-all-sky VHF system that utilizes four Yagi T/R (Transmit/Receive) antennae pointed north, south, east and west and operates at 33.6 MHz. Each radar utilizes four 5-element Yagi T/R antennas. The systems utilize a $100 \mu$ s-wide pulse at a pulse 


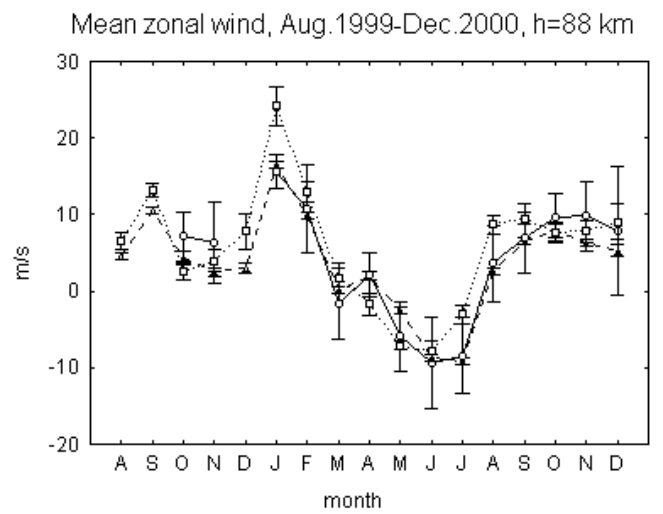

Mean zonal wind, Aug. 1999-Dec.2000, h=90 km
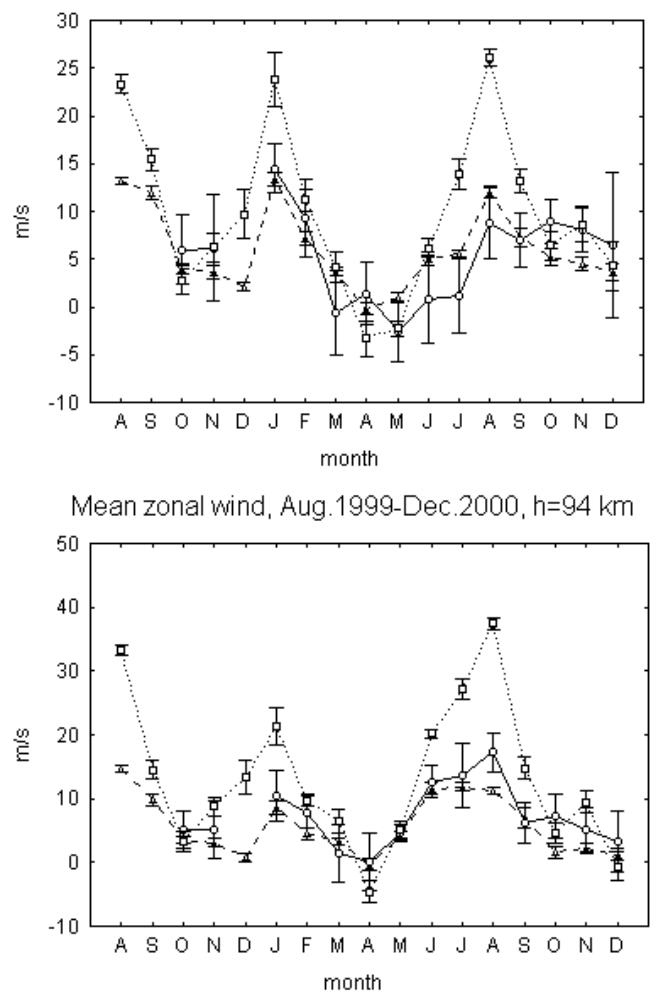

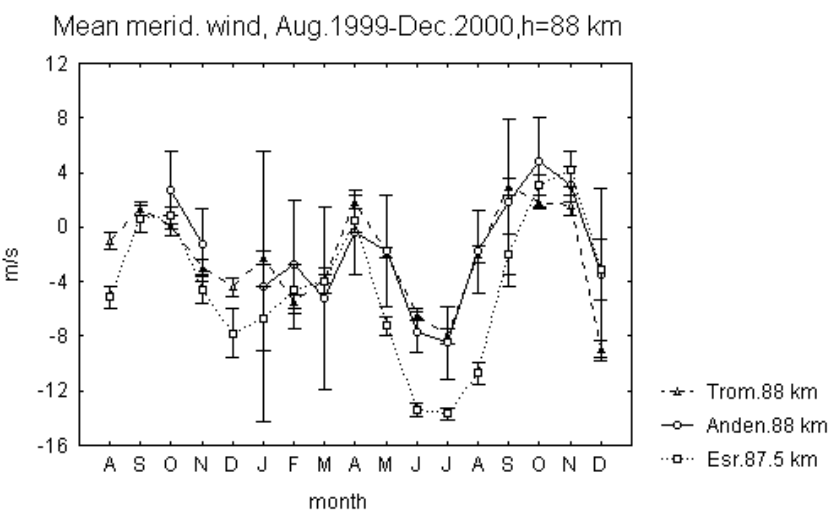

Mean meridional wind, Aug. 1999-Dec. $2000, \mathrm{~h}=91 \mathrm{~km}$

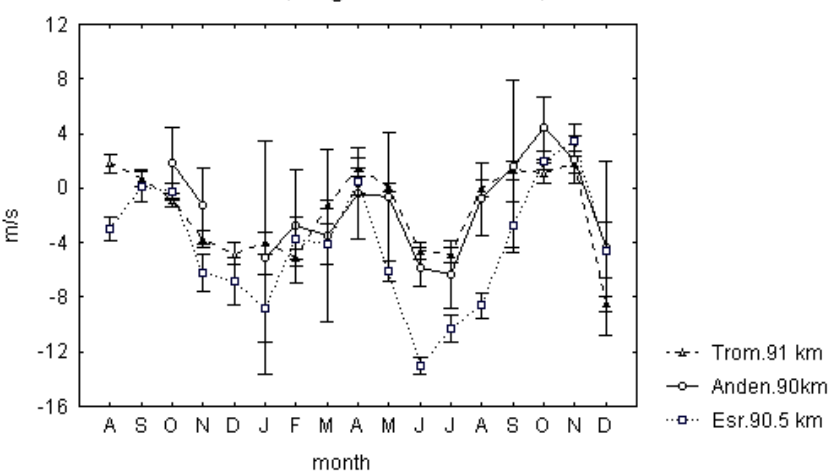

Mean merid wind, Aug. 1999-Dec. $2000, \mathrm{~h}=94 \mathrm{~km}$

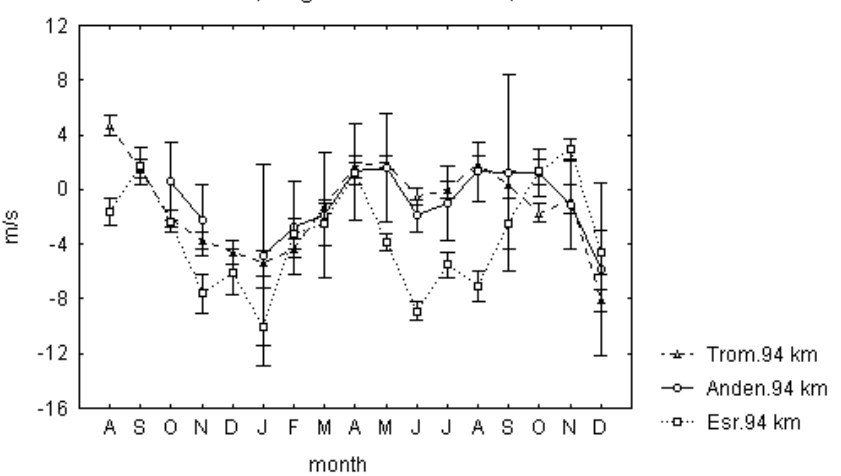

Fig. 1. (a) Monthly mean zonal wind measured at "Scandinavian triangle". (b) Monthly mean meridional wind measured at "Scandinavian triangle".

repetition rate of $100 \mathrm{~Hz}$ in search mode and $300 \mathrm{~Hz}$ in acquisition mode. The peak RF power for these systems is $10 \mathrm{~kW}$. Using a pulse width of $100 \mu$ s provides a range resolution of $15 \mathrm{~km}$; the data are all assigned to a nominal altitude of about $90 \mathrm{~km}-92 \mathrm{~km}$.

The regular observations commenced on September 1999. In the year 2002 COBRA-1 has been upgraded to the COBRA-II with height resolution.

\section{Esrange $\left(68^{\circ} \mathrm{N}, 2^{\circ} \mathrm{E}\right)$}

The Esrange meteor radar is a commercially produced VHF system manufactured under the brand name of SKiYMET
(Hocking et al., 2001a). The radar uses a solid-state transmitter of $6 \mathrm{~kW}$ peak power, and operates with a duty cycle of $15 \%$ at a frequency of $32.5 \mathrm{MHz}$. The repetition frequency is $2144 \mathrm{~Hz}$ and operation is pulse coded. Cross-element Yagi aerials are used for both transmitting and receiving. A single aerial acts as the transmitter and five aerials are used as receivers. The radar operates in an "all-sky" configuration with radiated power being largely independent of azimuth. The five individual receiver aerials are configured to act as an interferometer, which allows the determination of meteor echo azimuth and elevation angles. The elevation angle measurements in combination with measurements of the echo range allow meteor echo heights to be estimated with 

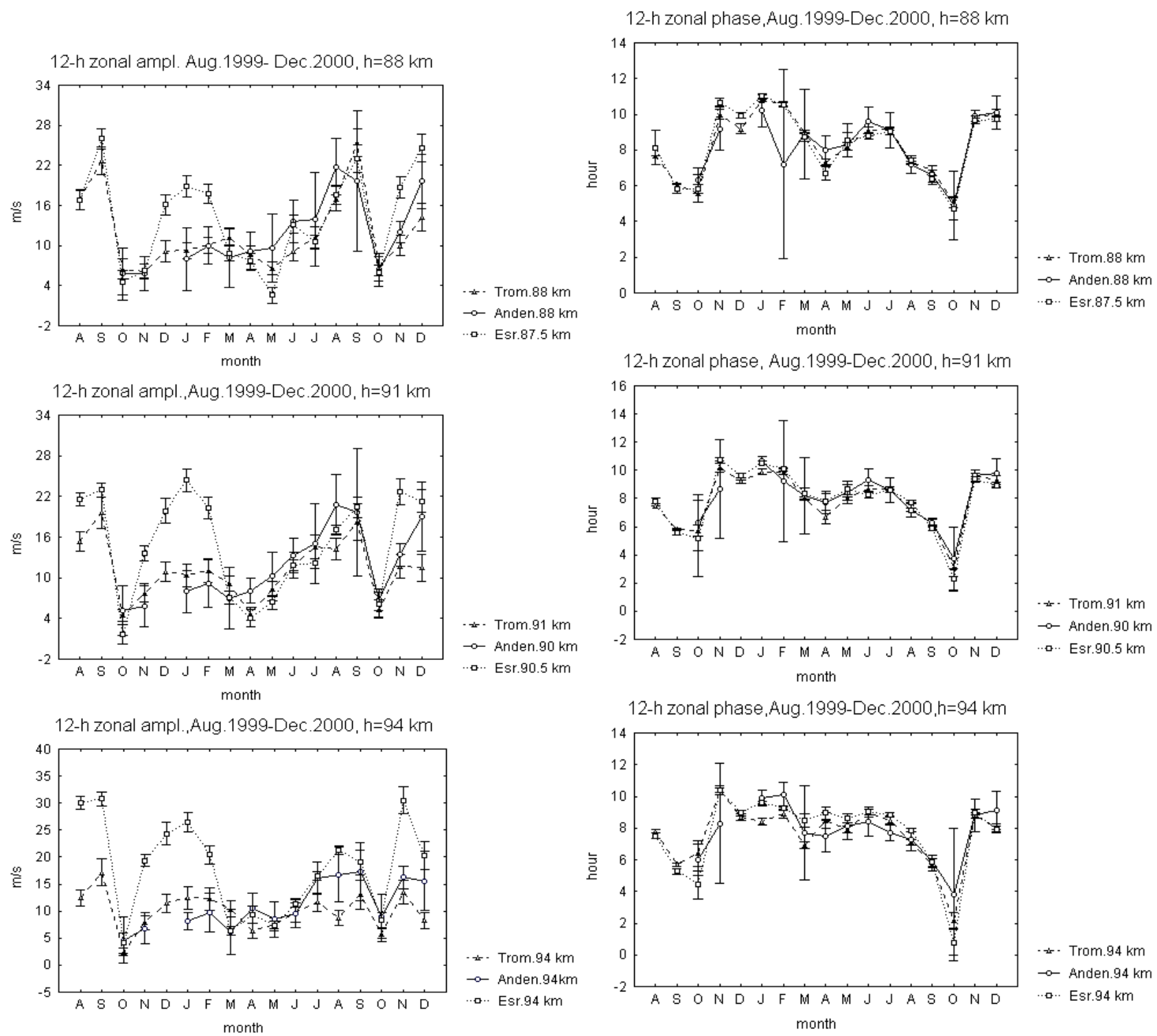

12-h zonal phase,Aug. $1999-D e c$. $2000, h=94 \mathrm{~km}$

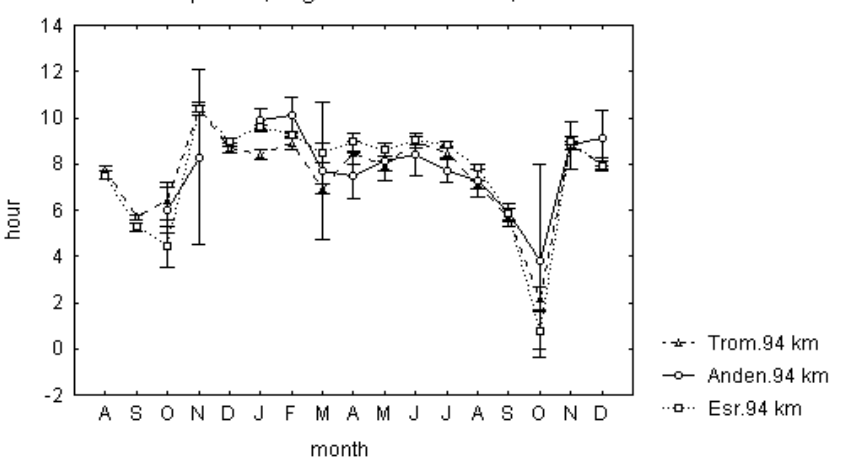

Fig. 2. (a) Monthly mean amplitudes of zonal component of the diurnal tide measured at "Scandinavian triangle". (b) Monthly mean phases of zonal component of the semidiurnal tide measured at "Scandinavian triangle".

a height resolution of typically $2 \mathrm{~km}$. Average height is estimated as $88-90 \mathrm{~km}$ and changing within $2 \mathrm{~km}$ during a day and seasonally. Continuous data collection commenced on 5 August 1999.

\section{Andenes $\left(69.3^{\circ} \mathrm{N}, 16^{\circ} \mathrm{E}\right)$}

The Andenes radar is an MF system, which operates at the frequency $1.98 \mathrm{MHz}$. Characteristics are as follows: pulse (27 $\mu$ s, Gaussian shape); height range, $60-94 \mathrm{~km}$; height resolution- $4 \mathrm{~km}$; sampling interval- $2 \mathrm{~km}$. The system has a 12-bit digitization width so that receiver saturation does not occurs. A square of half-wave dipoles is used on transmission. The receiving antennas are crossed half-wave dipoles arranged as a triangle with equal sides, and the transmitting antenna is located in its center. Observations commenced in January 1998.

\section{Poker flat $\left(65^{\circ} \mathrm{N}, 147^{\circ} \mathrm{W}\right)$}

The Poker Flat MF radar is similar to that at Andenes, but operates at the frequency of $2.43 \mathrm{MHz}$ (e.g. Kishore et al., 2002; Murayama et al., 2000). Three sets of crossed dipoles, spaced at $170 \mathrm{~m}$, are used for receiving. The radar uses a pulse length of $4 \mathrm{~km}$ but data are over-sampled at $2 \mathrm{~km}$ height intervals and observations are taken every $3 \mathrm{~min}$. The analysis is carried out in real-time using the conventional full correlation analysis (Briggs, 1984). At this site echoes 

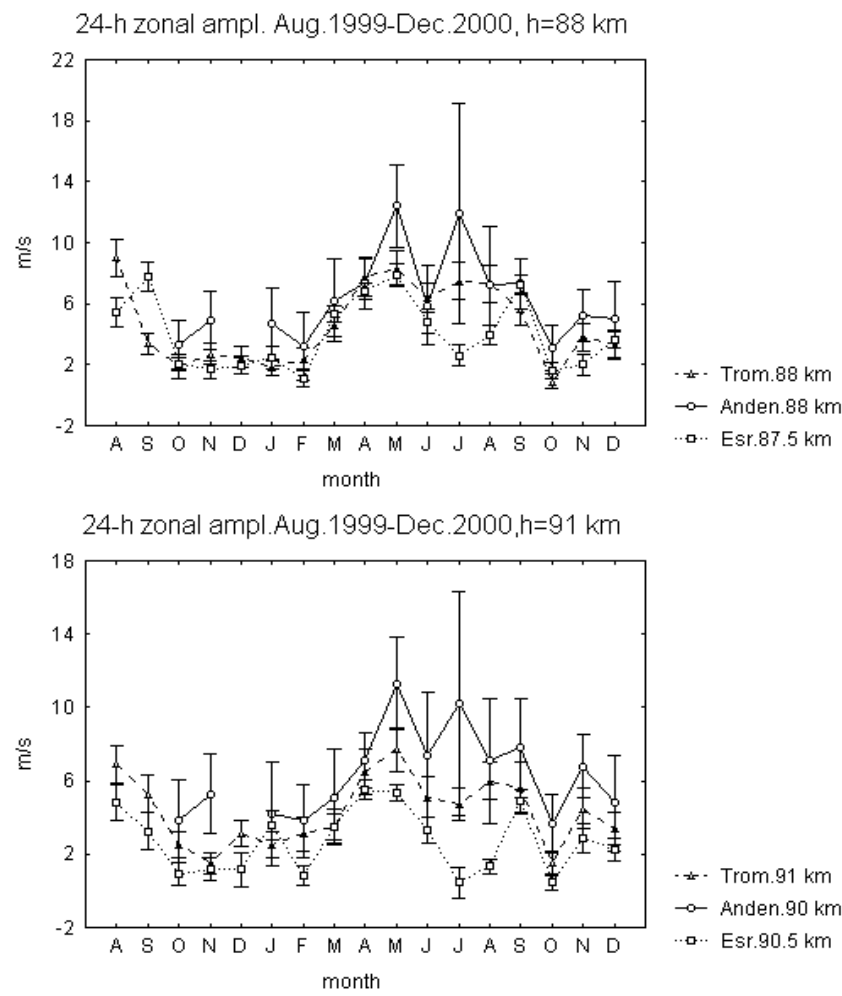

24-h zonal ampl.,Aug.1999-Dec. 2000, h=94 km

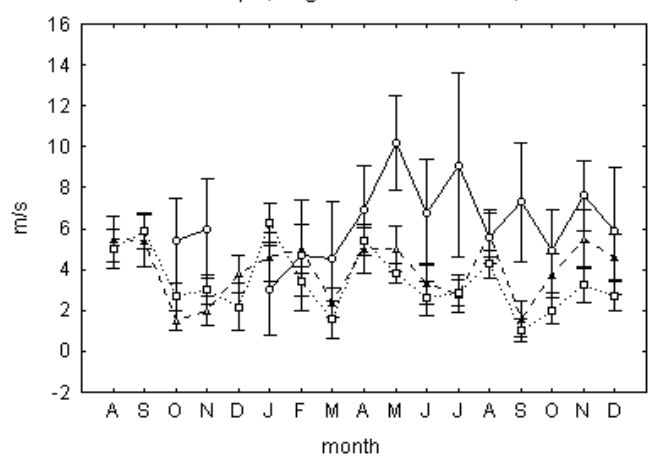

.2. Trom. $94 \mathrm{~km}$ $\rightarrow$ Anden. $94 \mathrm{~km}$ .... Esr.94 km 24-h zonal phase, Aug. 1999-Dec. $2000, \mathrm{~h}=88 \mathrm{~km}$

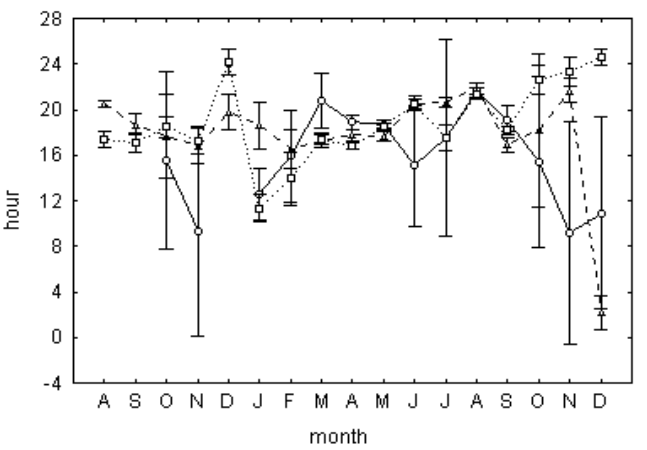

Trom $88 \mathrm{~km}$

- - Anden. $88 \mathrm{~km}$

$24 \mathrm{~h}$ zonal phase, Aug. 1999-Dec. $2000, \mathrm{~h}=91 \mathrm{~km}$

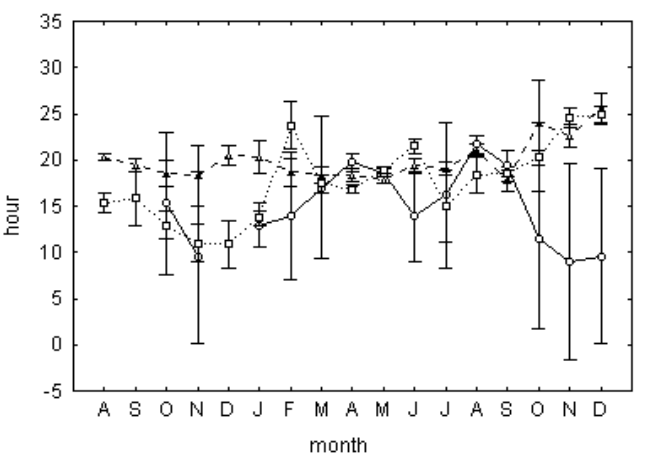

2. Trom.91 km $\rightarrow$ Anden. $90 \mathrm{~km}$ a.. Esr. $90.5 \mathrm{~km}$

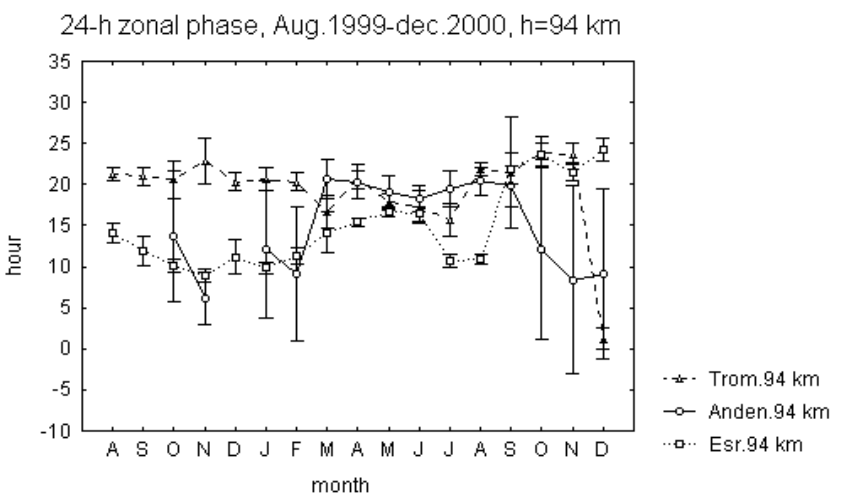

Fig. 3. (a) Monthly mean amplitudes of zonal component of the diurnal tide measured at "Scandinavian triangle". (b) Monthly mean phases of zonal component of the diurnal tide measured at "Scandinavian triangle".

are often available from altitudes as low as $50-55 \mathrm{~km}$. However, the data above $70 \mathrm{~km}$ are considered to be more reliable. E-region contamination could occur at Andenes above $92 / 94 \mathrm{~km}$ in summer and at Poker Flat about $2 \mathrm{~km}$ higher due to the slightly higher frequency used at Poker Flat. The Poker Flat radar became operational in October 1998.

\section{Point barrow $\left(7^{\circ} \mathrm{N}, 157^{\circ} \mathrm{W}\right)$}

This is a COBRA-II meteor radar. Characteristics are: frequency, $46.3 \mathrm{MHz}$; pulse duration, $80 \mu \mathrm{s}$; repetition frequency, $400 \mathrm{~Hz}$; peak power, near $10 \mathrm{~kW}$; antennas, four 6 -element T/R Yagi plus 5 cross-dipoles for interferometery, with one of them in the center; 6 channel receiver. Observations were commenced in May 2002.

\section{$\operatorname{Tromsø}\left(\mathbf{7 0}^{\circ} \mathbf{N}, \mathbf{1 9}^{\circ} \mathrm{E}\right)$}

The Troms $\emptyset$ MF radar $(2.78 \mathrm{MHz})$ is located at the EISCAT site of Ramfjordmoen $\left(70^{\circ} \mathrm{N}, 19^{\circ} \mathrm{E}\right)$ and has been described in particular by Hall (2001). The MF radar system in northern Norway became operational in 1975 . The time series obtained from the spaced receiver antennae are analyzed using a variant of the Full Correlation Analysis (Meek, 1980).

The data set collected from each site consists of monthly mean parameters of prevailing winds, semidiurnal and diurnal tides (amplitudes and phases) for every year. Climatic characteristic were obtained by averaging monthly mean pa- 

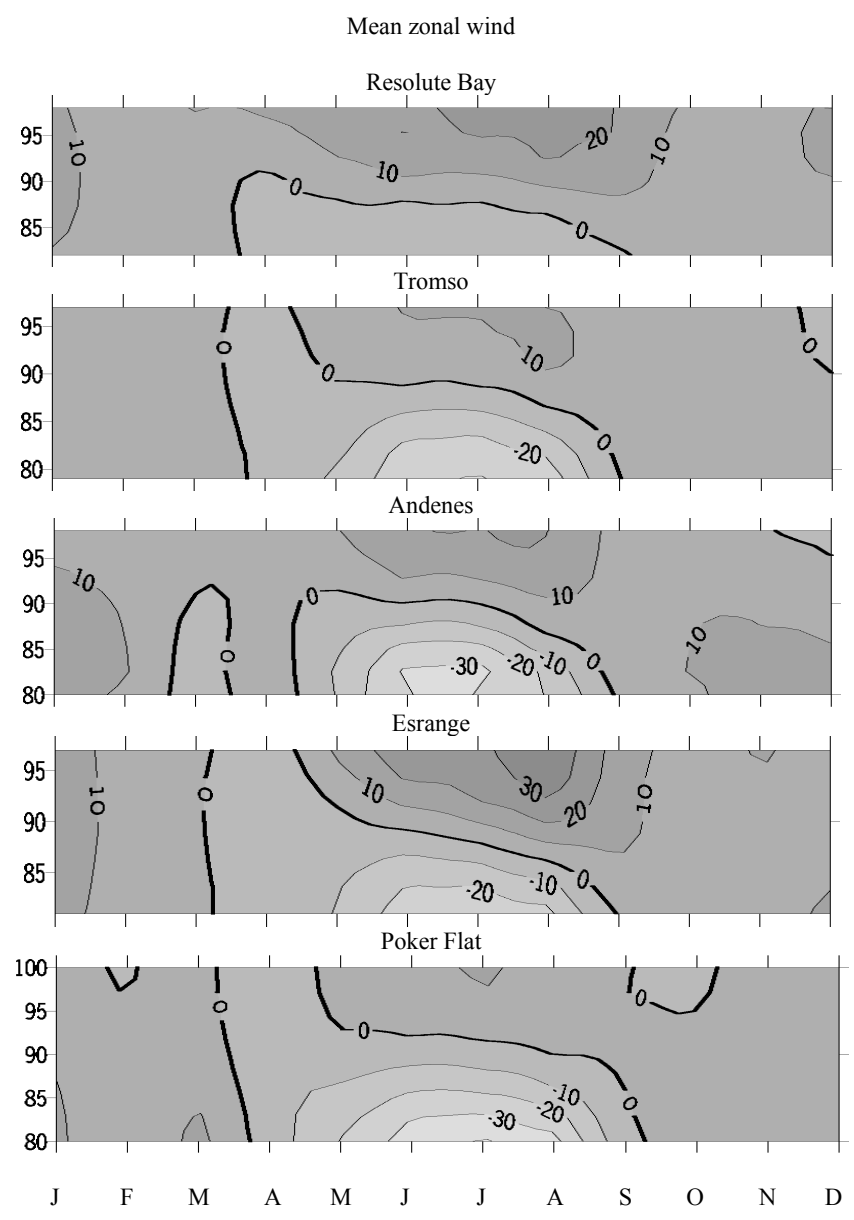

Fig. 4. Monthly mean zonal wind (m/s) measured at Arctic stations. Left axis is height $(\mathrm{km})$, horizontal axis shows month of year.

rameters over all available years at each site. So-called "vector averaging" was applied, i.e. we take into account amplitudes and phases for averaging the tidal parameters.

\section{Comparison of the different measurement techniques}

As it can be seen from Sect. 2, the equipment which is used for wind measurements in different locations is not identical. Hence, to reveal geophysically significant differences between the measurements at different sites, a comparison of winds and tides obtained with the different techniques should be carried out, using radars at closely spaced locations. Fortunately, the three radars of the Scandinavian Triangle (a meteor radar (MR) at Esrange, and two MF radars at Troms $\varnothing$ and Andenes) are situated rather closely to each other: Troms $\varnothing$ is $125 \mathrm{~km}$ east of Andenes, and Esrange is $202 \mathrm{~km}$ south-east of Troms $\varnothing$. A comprehensive comparison of the data, obtained at these stations, as well as detailed analyses of the limitations and capabilities of the two techniques, are the main issue of another paper (Manson et al., 2004a). Here we will only show some results of a comparison of the seasonal wind and tidal variations, measured simultaneously over the Scandinavian Triangle.

In Fig. 1 the seasonal variations of the zonal and meridional prevailing winds at the three height levels are shown. The winds from the $94 \mathrm{~km}$ altitude are not usually used from the MF radars during summer months, due to group retardation effects (Manson et al., 2004a). It can be easily seen from these plots that the general character of seasonal variations of the winds at all three sites is very similar, particularly at the lowest level about $88 \mathrm{~km}$. However, the meteor radar data (Esrange) shows a clear tendency toward stronger winds in the solstice seasons, and at times the directions of the MR and MF meridional winds are not the same. Consistent with this, the seasonal height contour plots shown by Manson et al. (2004a) also demonstrated a 3-4 km lower reversal height for the zonal wind in summer at Esrange, and an associated extended period of southward flow. It was noted that this could be associated with the latitudinal trend in zonal wind noted elsewhere.

The seasonal variations of the zonal components of the parameters of semidiurnal and diurnal wind variations are presented in Fig. 2 and Fig. 3. Again, the main features of the seasonal variations of these parameters are in good agreement for all parameters, especially for the phases of the relatively large semidiurnal tide. However, during the winter season, significant differences between the MF and MR data are seen for the amplitudes of the semidiurnal tide, when larger amplitudes are observed by the MR radar. For the amplitudes of the diurnal tide in summer months, sometimes the differences between the Andenes MF and Troms $\varnothing$ MF radar data are larger than between the Esrange MR and Troms $\emptyset$ MF data. Often the Esrange MR amplitudes are the smallest. There is also much more variability in the phases of the diurnal tide across the Scandinavian Triangle than for the other tide. This was also noted by Manson et al. (2004a). We note that the amplitudes of the diurnal tide are often very small $(2 \mathrm{~m} / \mathrm{s})$, and that this may contribute to the variability noted here. The same features are also found for the meridional component of the tidal parameters (not shown here).

This comparison gives an impression about the order of magnitude of the differences between the measurements, obtained with different types of instruments, situated at relatively closely spaced locations. There is certainly a wind speed difference between the MF and MR systems used here, and Manson et al. (2004) showed this to be 1.6 (the MR being larger) at $97 \mathrm{~km}$ and 1.1 at $85 \mathrm{~km}$. It also has to be pointed out that, according to Manson et al. (2004a), altitudes higher than $90 \mathrm{~km}$ often cannot be reached by the MF radar pulses without significant group-retardation or total reflection. Hocking (1997) has also noted that because the E-region echoes are often one or two orders of magnitude stronger than the $90 \mathrm{~km}$ echoes, the $90 \mathrm{~km}$ winds can be affected by the fading of the tail of the E-region pulse at $90 \mathrm{~km}$, biasing the results at $90 \mathrm{~km}$ and above. These may possibly be reasons for the observed differences between the MR and MF data. This may be a reason for some of the observed differences between the MF and MR data. The different elevation an- 

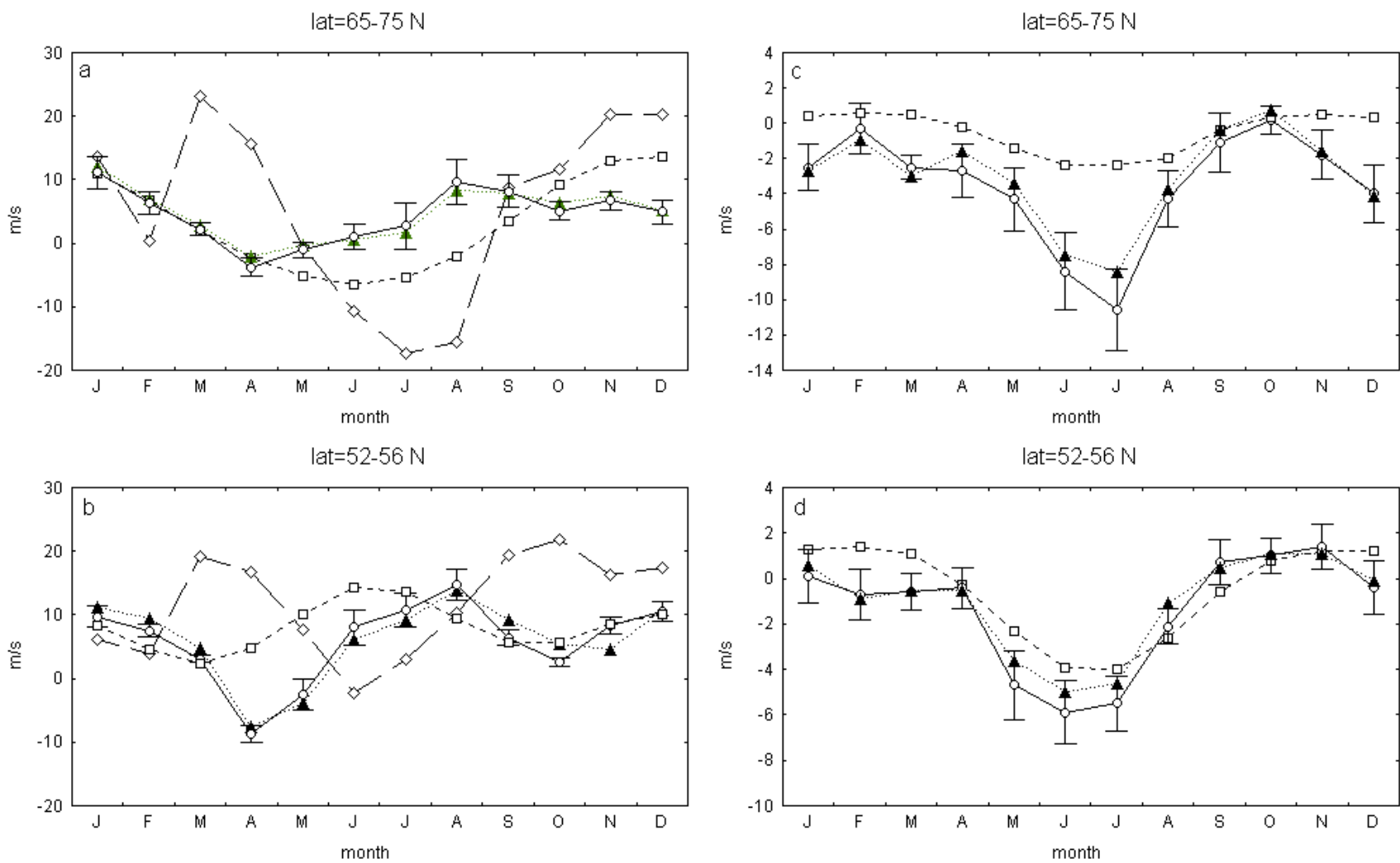

Fig. 5. The zonally averaged seasonal course of the prevailing wind at $90 \mathrm{~km}$; the error bars correspond to the r.m.s. (standard) errors: (a), (b) - zonal wind (eastward positive), (c), (d)-meridional wind (northward positive). - o- experimental data, --HWM-93, ... $\mathbf{\Delta}$...GEWM-I, $-\diamond-$ CIRA-86.

gles of the antennae beams of the MF and MR radars, errors in the assumed pointing angles of the antennas, the lack of coinciding sampling volumes, and related latitudinal variations in the placement of these instruments, may also be contributing reasons for these differences. This should be taken into account when considering the results of the intercomparison between the monthly mean wind values for different geographical locations of the DATAR system.

\section{Prevailing (mean) winds}

\subsection{Zonal prevailing wind}

In Fig. 4 the mean contour plots of the zonal prevailing winds for 5 Arctic stations are shown. In this figure the zero-wind line is marked with a heavy contour. It can be seen that the main features of the height-seasonal zonal wind variations are common for all the stations.

During the winter season the zonal winds at all observational sites are eastward at all heights. These winds may be considered as a manifestation of the winter cyclonic jet, which extends from the mesosphere to the lower thermosphere. The strength of the winds and their vertical gradients do not completely coincide at different sites. The observed differences cannot be considered as longitudinally dependent, because even at the Scandinavian Triangle stations the zonal winds are significantly different. Between March and April the spring circulation reconstruction process is commenced. As a result rather weak westward winds, which extend for the most of the sites over the whole height range during these months (the exception is Resolute Bay and Andenes), are observed. After April-May at the lower thermosphere heights the eastward winds are restored, while at the upper mesosphere heights the westward winds appear.

In June-August below about $90 \mathrm{~km}$ (i.e. near to the mesopause level) at Troms $\varnothing$, Andenes, Esrange and Poker Flat, the well-expressed westward winds of the mesospheric summer anticyclone are observed, which for this season are typical of the middle latitudes as well. These winds have rather strong vertical shears. The position of the zerowind line during this season at Resolute Bay and Esrange is slightly lower than that for the other 3 station, and the strength of the westward wind and its vertical gradient at Resolute Bay are also definitely less in comparison with the other sites. In the Arctic lower thermosphere during this season, eastward winds are observed at all sites, thus indicating the existence of a summer cyclonic vortex.

In the autumnal equinox the eastward winds are decreased to rather small values of about $5 \mathrm{~m} / \mathrm{s}$, but these winds are extended for the whole height region, including the mesosphere heights. Then a gradual transition to the winter circulation occurs. 

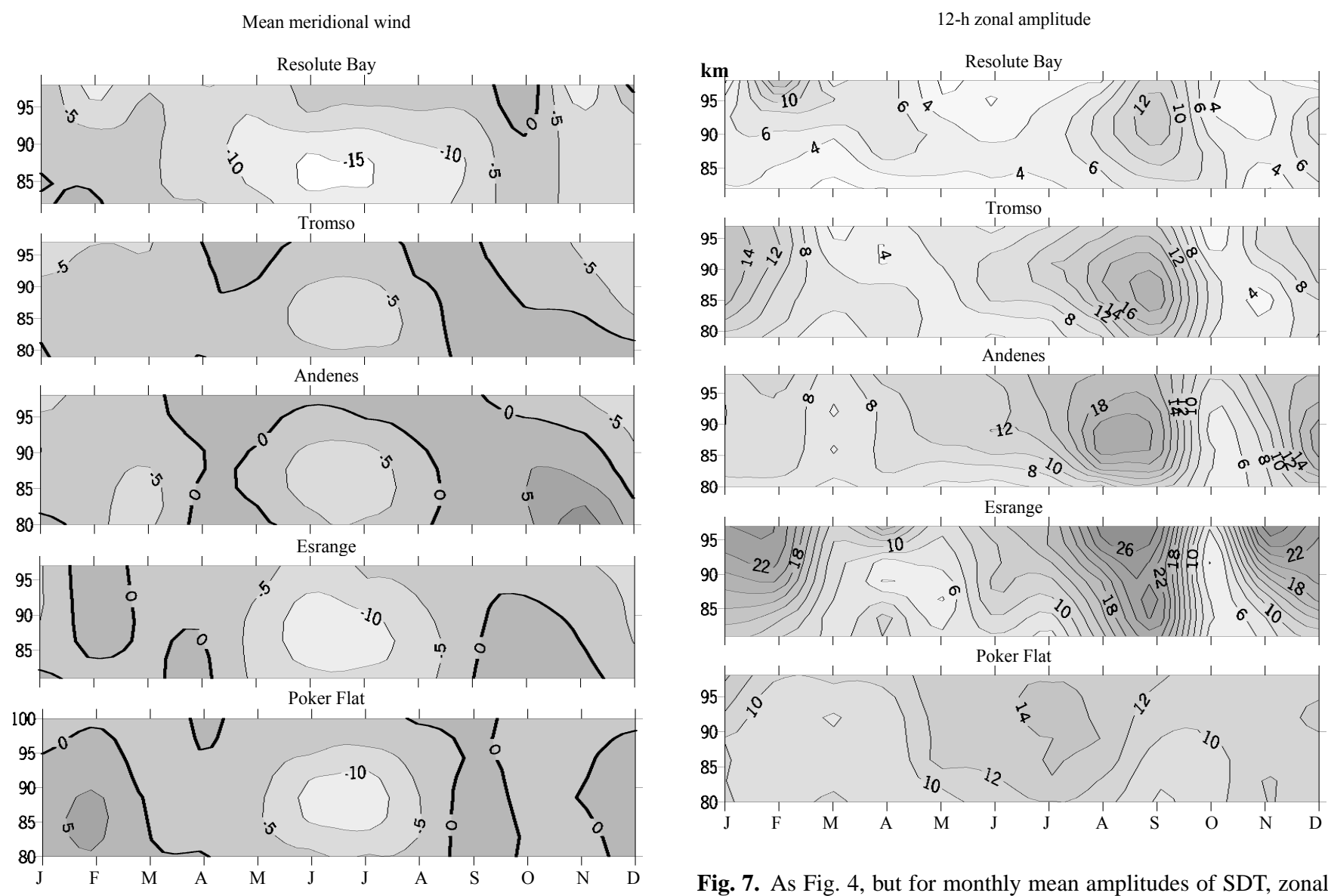

Fig. 6. As Fig. 4, but for monthly mean meridional wind.

As an example, Fig. 5a, b demonstrates a comparison of the seasonal variations of the experimental monthly mean zonal winds at about $90 \mathrm{~km}$ for two latitudinal belts: $65-$ $75^{\circ} \mathrm{N}$ (Fig. 5a) and $45-55^{\circ} \mathrm{N}$ (Fig. 5b) with the existing empirical wind models. The experimental data were calculated by averaging all monthly mean data for the particular sites, located in these belts. The error bars shown correspond to the r.m.s deviations and comprise longitudinal, latitudinal as well as the instrumental variability of the monthly mean values. The updated global empirical wind model (GEWM-I) (Portnyagin et al., 2000, 2004a) was used for comparison. When constructing this model all high-latitude radar wind data, pointed out in Table 1, as well as the data from the other stations over the globe, were assimilated in the uniform fashion. The CIRA-86 model (Fleming et al., 1988) and the HWM-93 (Hedin et al., 1996) models were also used for comparison. It can be easily seen from Fig. 5 that the GEWM-I adequately reproduces the mean experimental data, while the CIRA-86 and HWM-93 differ significantly from that. This is also true for other height levels.

The difference between the seasonal variations of the zonal mean winds at high and moderate latitudes is mainly expressed in amplitudes of seasonal variability. As could be anticipated, the mean zonal wind gradually decrease to the pole. In general, as is seen in Fig. 5 and in similar figures

for other heights (not shown here), the zonal winds vary very regularly with season, so that we may conclude that the seasonal variations of the mean zonal wind are the most distinctly expressed climatological feature of the wind regime in the MLT region. Finally, it would be of interest to point out that the r.m.s. deviations, shown in Fig. 5, demonstrate a definite seasonal dependence with the maximum in the summertime.

\section{Meridional prevailing wind}

The monthly mean meridional prevailing winds measured by the 5 Arctic radars are presented in Fig. 6. The most distinguishing feature for all these contour plots is a dominating equator-ward flow during much of the year. The strongest winds are observed in summer, with maximum around -10 to $-15 \mathrm{~m} / \mathrm{s}$ near at the summer solstice, when the strongest zonal wind vertical gradients are revealed. This maximum of equatorward winds is centred at about $88 \mathrm{~km}$. During the other seasons the direction of the meridional wind is more variable and the wind becomes weaker. It should be pointed out that even at the closely located stations (Scandinavian triangle) in some months the direction and the strength of the meridional wind are significantly different. 
Similar differences were noted by Hall et al. (2003) between Troms $\varnothing\left(70^{\circ} \mathrm{N}\right)$ and Svalbard $\left(78^{\circ} \mathrm{N}\right)$.

In Fig. 5c, $d$ the seasonal variations of the observed monthly mean meridional winds at about $90 \mathrm{~km}$ for two latitudinal belts $\left(65-75^{\circ} \mathrm{N}\right.$ (Fig. 5c) and $45-55^{\circ} \mathrm{N}$ (Fig. 5d)) are compared with the existing empirical wind models: GEWMI and HWM-93 ( CIRA-86 model does not contain the meridional winds). It is seen from these figures that the GEWM-I gives the best fit to the experimental data. Contrary to the expectations from the HWM-93 model the experimentally observed meridional winds do not simply decrease toward the pole. Possibly this is a manifestation of the cellular structure of the mean meridional wind (Portnyagin et al., 1997; Fauliot et al., 1997; Hall et al., 2003)). It is important to mention that as in the case of the mean zonal wind, the seasonal variations of the meridional wind are very regular. This conclusion is confirmed by our similar analysis for other heights.

\section{Semidiurnal tide}

In this section we will consider the main climatological features of the seasonal variations of the 12-h MLT wind variations. The 12-h oscillations are usually regarded as a manifestation of the 12-h tidal wave (SDT), which propagates westward following the apparent motion of the Sun. The contours of the monthly mean amplitudes of this oscillation for all the sites with height resolution are shown in Fig. 7 for the zonal component and in Fig. 8 for the meridional one. In general, the seasonal courses of these amplitudes are similar. As a rule the largest amplitudes are observed at the all heights in August-September (but in July for the zonal component at Poker Flat and for the meridional component in the lower thermosphere at Andenes). Again, some caution must be used for the data above $92 \mathrm{~km}$ for the MFR sites, due to radar group retardation. During this period the amplitudes attain their maximum near the mesopause heights and then become saturated and even decreased in the lower thermosphere (with some exceptions for both components at Esrange and for meridional component at Andenes, where the maximum is observed somewhere higher $95 \mathrm{~km}$ ). Riggin et al. (2003) considered some mechanisms related to the autumn intensification of SDT and to features of the amplitude height profile following the study of high-latitude radar measurements. A secondary maximum is observed during winter. From March to June a rather extended period of reduced amplitudes is apparent, while in October/November an abrupt decrease of the amplitudes is observed (not so well expressed at Poker Flat).

Figure $9 a, b$ presents the averaged seasonal course of the 12-h amplitudes at about $90 \mathrm{~km}$ for the Arctic latitude belt and for the mid-latitude belt. The result for the meridional tidal component is shown. The corresponding figure for the zonal tidal component is not shown because it is similar to Fig. 9. It should be underlined that despite intrinsic height averaging of the data at Dixon (and Heiss), the Resolute Bay measurements (with height resolution) show variations of 12-
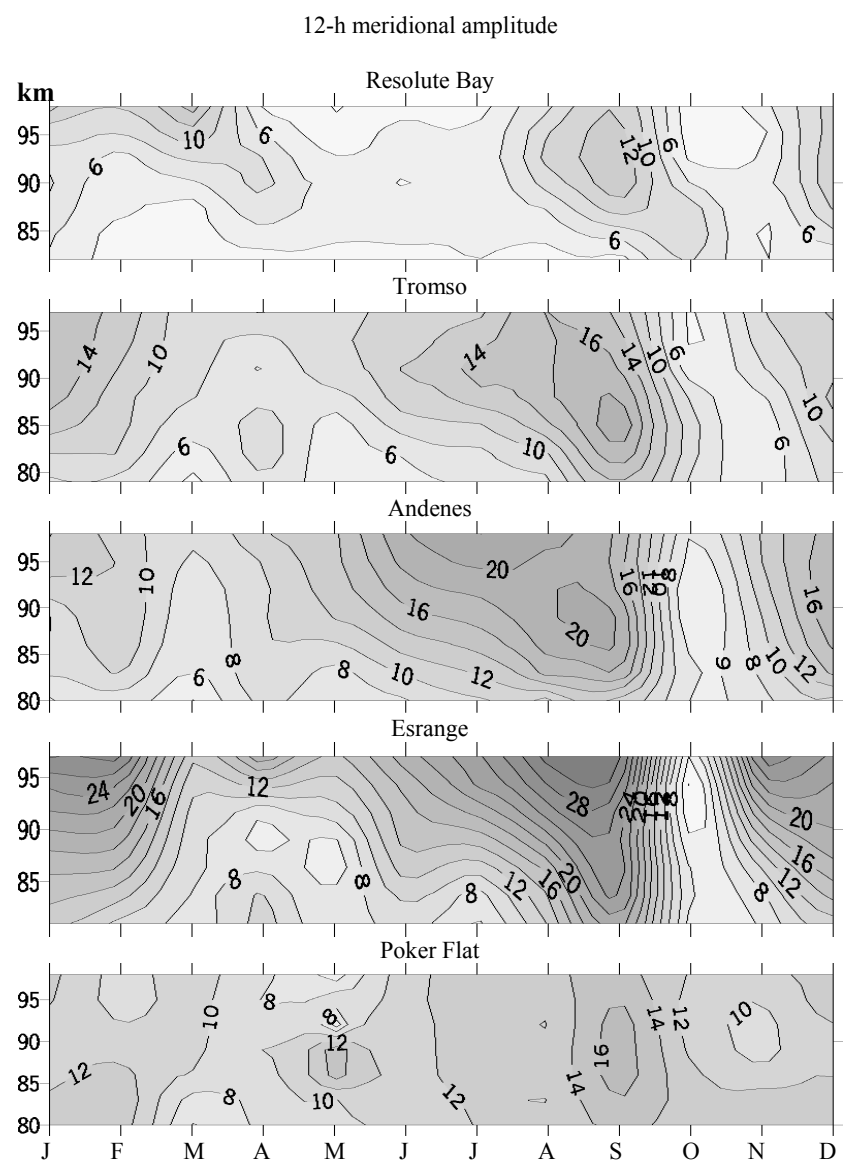

Fig. 8. As Fig. 7, but for monthly mean amplitudes of SDT, meridional component.

$\mathrm{h}$ amplitudes that are very close to those at Dixon. The estimated zonally averaged vertical wavelengths of this oscillation do not significantly differ for the high and moderate latitudes. Actually, we have estimated the vertical gradient of the tidal phases and therefore the values of the vertical wavelength are just inverse vertical gradients. For example, for the summer season in all cases the vertical wavelengths exceed $200 \mathrm{~km}$.

The comparison of the observed zonal mean semidiurnal tide parameters (amplitudes and phases) at the high and moderate NH latitudes with the expectations from the HWM-93 (Hedin et al., 1996) and GEWM-II empirical wind models at $90 \mathrm{~km}$ is also shown in Fig. 9a, b, c, d. The method of the GEWM-II construction is described in Portnyagin et al. (1998), while the database used is the same as that described in Portnyagin et al. (2004). In general, the main regularities of the seasonal variations of the Arctic 12-h wind oscillation parameters resemble those observed in the $\mathrm{NH}$ mid-latitudes (see, also, Manson et al., 1999, 2002a; Jacobi et al., 1999). The GEWM-II is in a rather good agreement with the experimental data, while the HWM-93 underestimated the 12-h tide amplitudes in the May-September period, especially in high latitudes. In the April-August period for moderate latitudes the HWM-93 model predicts signif- 
lat $=65-75 \mathrm{~N}$

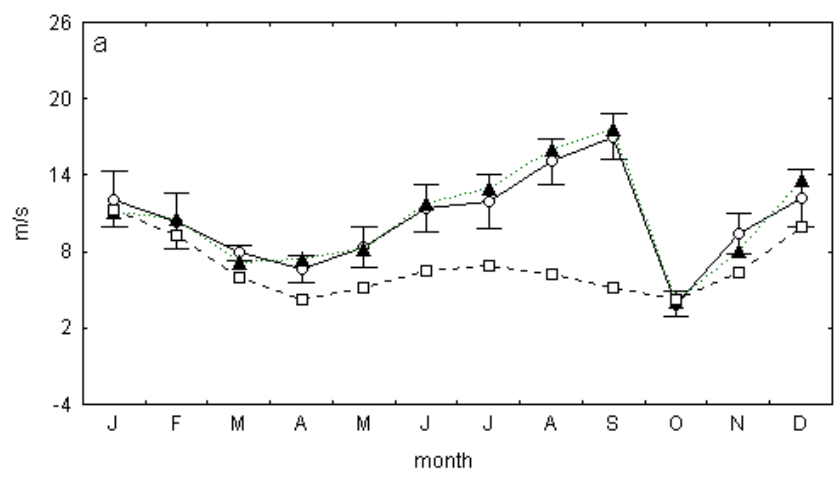

lat $=52-56 \mathrm{~N}$

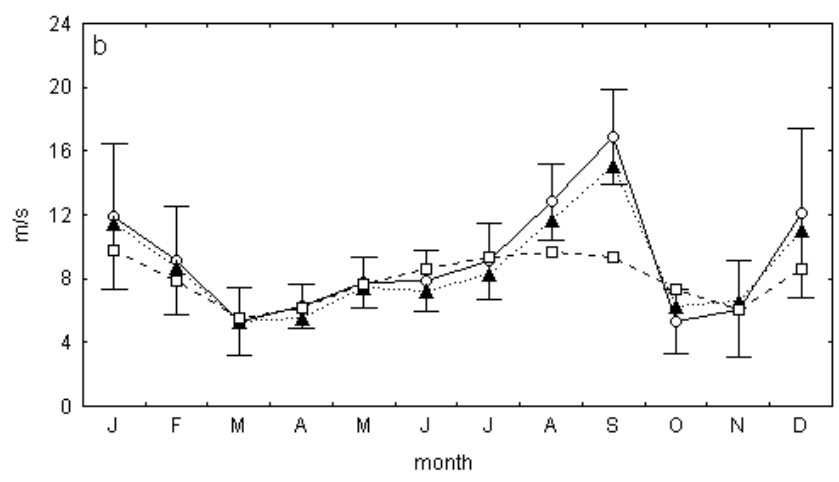

lat $=65-75 \mathrm{~N}$
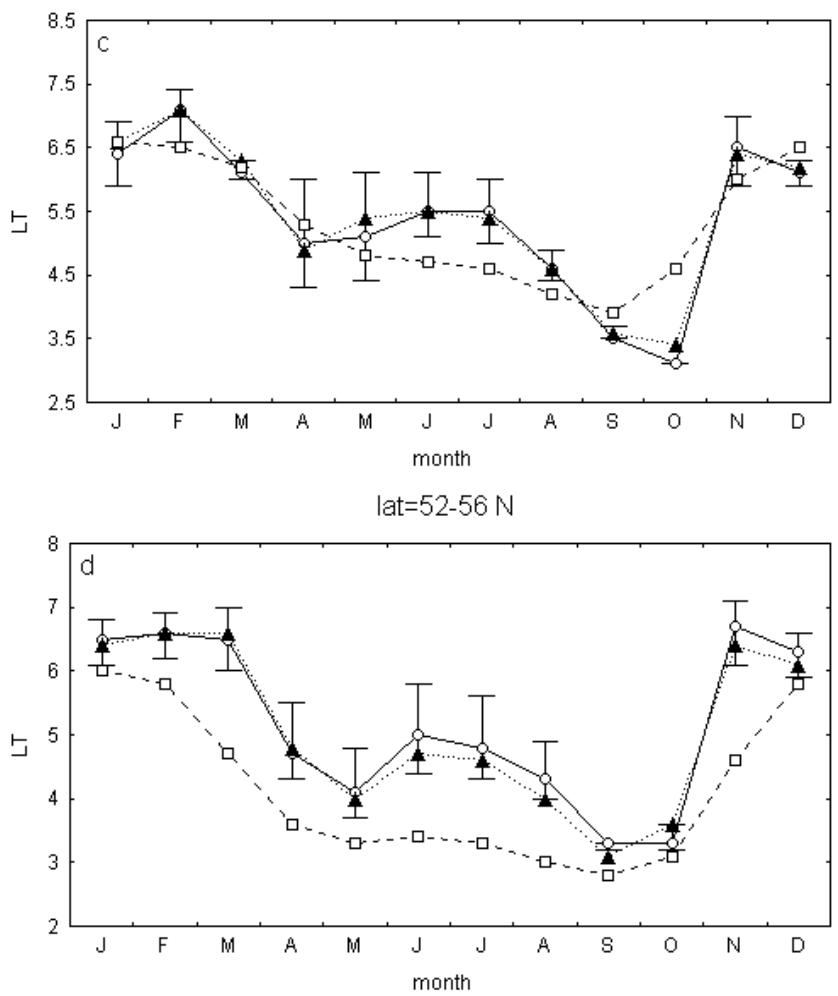

Fig. 9. The zonally averaged seasonal course of the semidiurnal tide at $90 \mathrm{~km}$; the error bars correspondend to the r.m.s. errors for vector averaged values: $(\mathbf{a}, \mathbf{b})$-amplitude of meridional component, $(\mathbf{c}, \mathbf{d})$-phase of maximum of meridional component. -o- experimental data, -- $\square--$ HWM-93, ... ...GEWM-II.

icantly lower phase values than that from the experimental data and the GEWM-II.

Merzlyakov et al. (2003) have demonstrated that seasonal variability of the $12 \mathrm{~h}$ wind oscillation obtained by identical instruments at Dixon and Obninsk are very similar. Parameters of annual and semiannual oscillations of the 12-h amplitude were observed to be practically the same for mid- and high-latitudes during year 2000. The monthly mean phase values of the 12-h oscillation are close for both components at Obninsk and Dixon. All these results suggest that the 12-h oscillation in high- and mid-latitudes of NH should be mainly related to the migrating semidiurnal tide, unless the longitudinal structures associated with non-migrating tides are similar at both latitude ranges, for example, if they are linked to continental-scale forcings (Manson et al., 2002b). Supplementary information about the longitudinal structure of the observed Arctic 12-h wind oscillation may be obtained from analysis of the phases of this oscillation. In Fig. 10 the dependence of the 12-h phases (time of maximum in UT) on longitudes for different months is shown. The fit and slope errors were obtained by a linear regression analysis. To check the presented results we applied the same analysis to the phases in LT. For this case the slopes have to decline from 0 if there are inputs from non-migrating tidal components. Both approaches gave the similar slopes and error bars. Several significant features are obvious when consider- ing this figure: a) the meridional component leads the zonal one (clockwise wind vector rotation); b) the shift between the zonal and meridional phases on average is close to $3-\mathrm{h}$ (or sometimes smaller), thus indicating that the zonal and meridional components are close to being in quadrature; $c$ ) the longitudinal dependence of the phases is rather definite and permits us to determine the zonal wave number; d) the zonal wave number for the both components is close to $s=2$ or slightly less. Additional information about the variations of the zonal wave numbers from month to month may be found in Table 2. When analyzing this table we may conclude that for all months of the year the zonal wave numbers are near to, or dominated by, $s=2$. The lowest wave numbers for both components are determined in May-June and in November. In September, when the 12-h amplitudes achieve their maximum, the zonal wave numbers are very close to the value $s=2$, which is characteristic of the migrating semidiurnal tide. The zonal wave numbers lower than $s=2$ may be considered as an indication of the possible interference between the migrating and non-migrating semidiurnal tide. It is now well known that during austral summer in the Antarctic near to the Pole, the dominant semidiurnal oscillation is characterized by the zonal wave number $s=1$ (Forbes et al., 1995; Portnyagin et al., 2000). According to the theory (see, for example, Longuet-Higgins, 1968) the migrating semidiurnal tide with $\mathrm{s}=2$ has to vanish at the Poles. 
12-h phase, January, $\mathrm{h}=88 \mathrm{~km}$

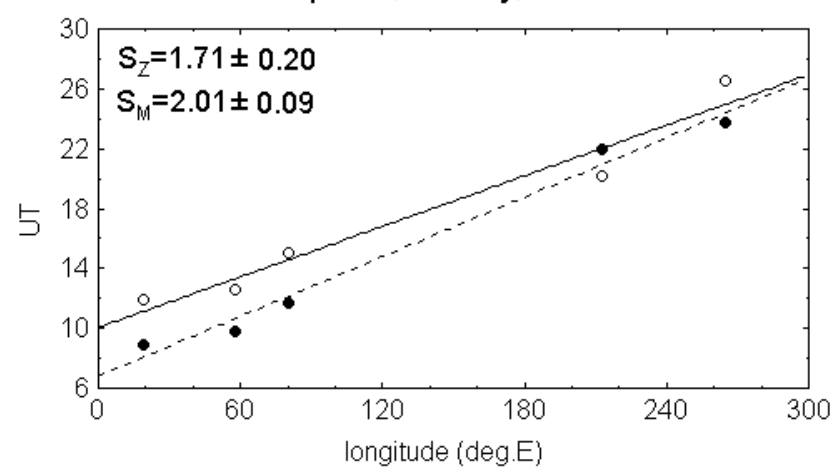

12-h phase, July, h=88 km

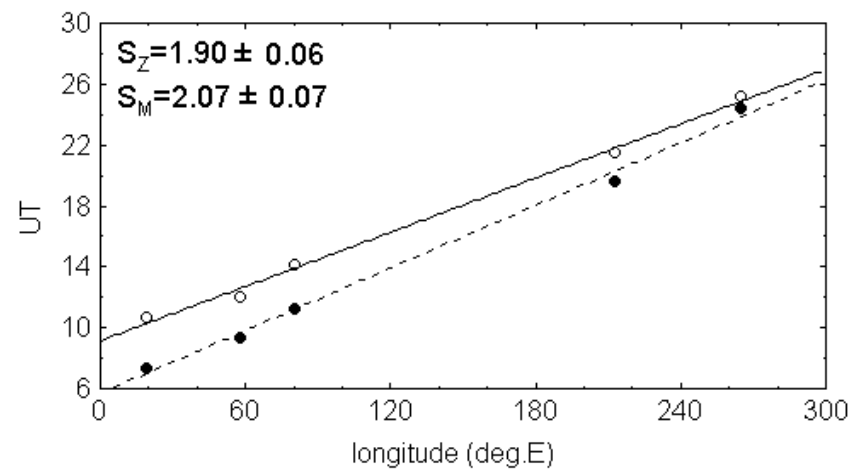

12-h phase, April, $\mathrm{h}=88 \mathrm{~km}$

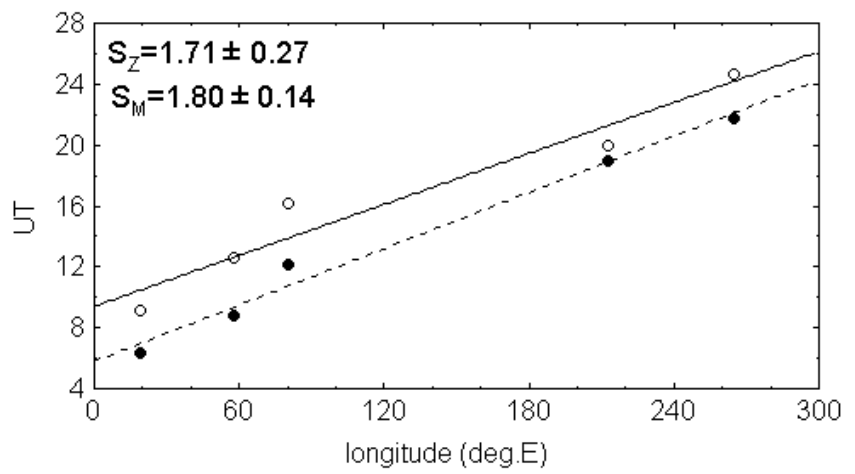

12-h phase, October, $\mathrm{h}=88 \mathrm{~km}$

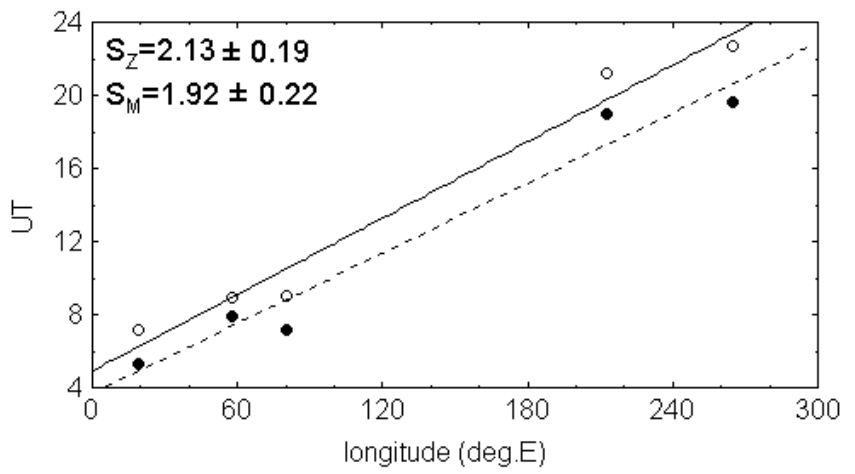

Fig. 10. Dependence of the SDT phases (time of maximum in UT) on longitude $-o-$ zonal component, $-\bullet-$ meridional component

Riggin et al. (1999), compared the MLT wind measurement results at McMurdo $\left(77.8^{\circ} \mathrm{S}\right)$ and Halley $\left(75.8^{\circ} \mathrm{S}\right)$ and pointed out that during seasons when the 12-h amplitudes are large, the zonal structure is highly unstable and there is not an obvious dominant zonal wave number. However, Murphy (2002), analyzing these results and their own MF radar measurements at Davis $\left(68.6^{\circ} \mathrm{S}\right)$, proposed that all these results may be explained by a combination of the two 12-h waves with $s=1$ and $s=2$ and concluded that the $s=1$ semidiurnal oscillation observed at the South Pole may extend equator-ward to $65^{\circ}$ latitude. It seems that the situation in the NH Arctic MLT region may be different from that in the SH. Apparently, in the latitudinal belt $67-80^{\circ} \mathrm{N}$ in the MLT region, the migrating semidiurnal tide dominates during all months, while additional non-migrating components play a secondary role. Consistent with this, the recent studies of non-migrating tides by Manson et al. (2002b, 2004b), using HRDI-UARS data at $95 \mathrm{~km}$, reached to $70^{\circ} \mathrm{N}$ in summer and fall, and concluded that these semidiurnal tides were weak compared with the migrating tide. However, to reach more decisive conclusions more experimental data are necessary.

\section{Diurnal tide}

The contour plots of the amplitudes of the 24-h oscillation (DT) are shown in Figs. 11 and 12. The similarity between the plots for different stations is not as obvious as in the
Table 2. Phase of 12-h oscillation (LT).

\begin{tabular}{lcc}
\hline Month & Zonal comp. & Merid. Comp. \\
\hline January & $1.71 \pm 0.20$ & $2.01 \pm 0.09$ \\
February & $1.71 \pm 0.30$ & $2.07 \pm 0.18$ \\
March & $1.83 \pm 0.33$ & $2.34 \pm 0.13$ \\
April & $1.71 \pm 0.27$ & $1.80 \pm 0.14$ \\
May & $1.56 \pm 0.17$ & $1.74 \pm 0.06$ \\
June & $1.59 \pm 0.18$ & $1.74 \pm 0.20$ \\
July & $1.80 \pm 0.06$ & $2.07 \pm 0.07$ \\
August & $1.89 \pm 0.33$ & $2.01 \pm 0.05$ \\
September & $2.07 \pm 0.12$ & $2.10 \pm 0.09$ \\
October & $2.13 \pm 0.19$ & $1.92 \pm 0.22$ \\
November & $1.68 \pm 0.19$ & $1.77 \pm 0.28$ \\
December & $1.68 \pm 0.19$ & $2.04 \pm 0.20$ \\
\hline
\end{tabular}

case of the 12-h oscillation. However, some common features are revealed from this plots: a) the smallest amplitudes are mainly observed in the winter months; b) a rather wide region of increased amplitudes up to about $10-15 \mathrm{~m} / \mathrm{s}$ is observed during the extended period from April to October; c) for some stations in the region of increased amplitudes the changes in the sign of the vertical gradient of the amplitudes 

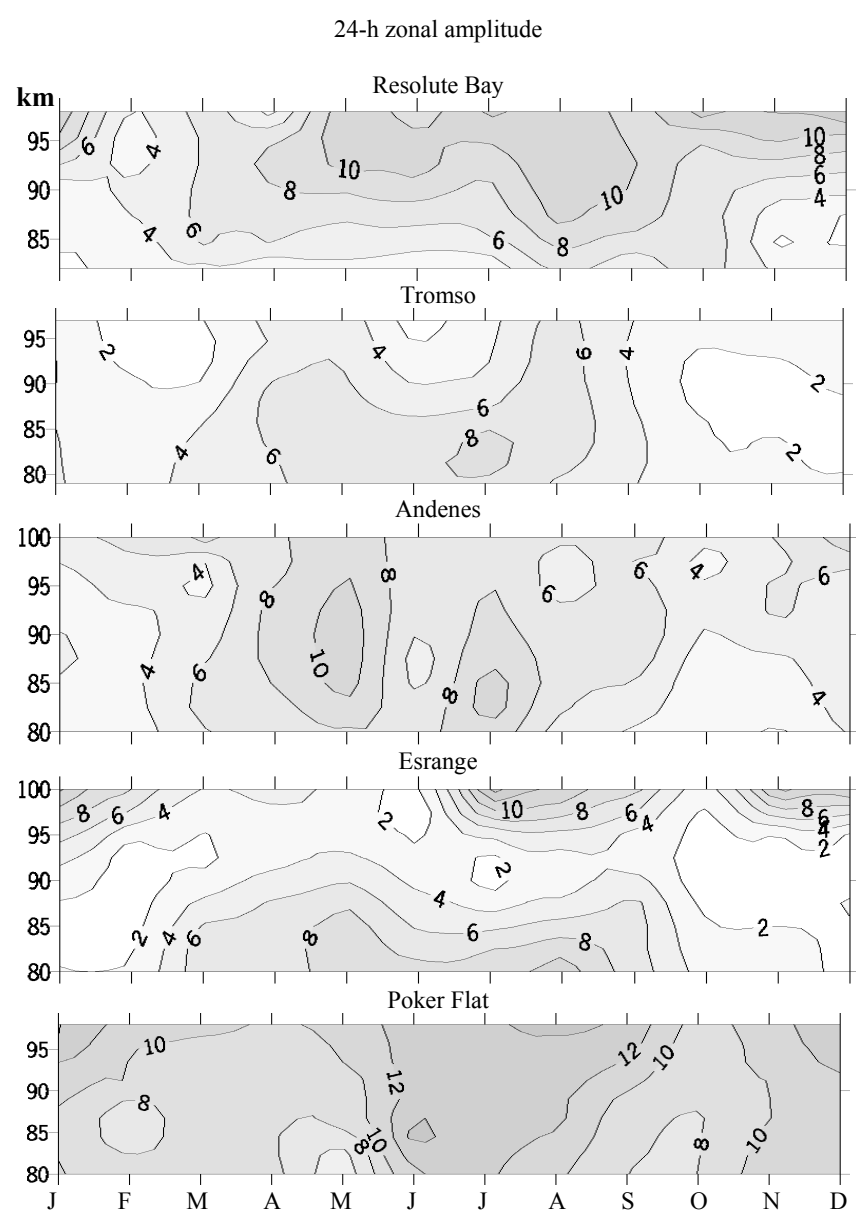

Fig. 11. As Fig. 7, but for monthly mean amplitudes of DT, zonal component.

from positive to negative are observed; d) on average the meridional amplitudes are larger than the zonal amplitudes. Features $\mathrm{a}-\mathrm{c}$ correspond well to the seasonal variability of the meridional tidal component at mid-latitudes (Manson et al., 1987), and to the Scandinavian Triangle results (Manson et al., 2004a). The same was also observed by Merzlyakov et al. (2003) for Dixon and Obninsk. Again, MF radar results above $92 \mathrm{~km}$ should be treated with some care due to E-region effects.

Along with common features, certain significant differences between the plots for different Arctic stations exist, indicating much more variable 24-h amplitudes in comparison with those of the 12-h ones. Additionally, the seasonal variations of the zonally averaged 24-h amplitudes and phases at about $90 \mathrm{~km}$ are presented in Fig. 13, which is similar in format to Fig. 9, but for the diurnal tide. Most of the discussed features can be seen in this figure. The error bars additionally illustrate the degree of the 24-h amplitude variability. The comparison of the observed zonal mean diurnal meridional tide parameters with the expectations from the HWM-93 (Hedin et al., 1996) and GEWM -III empirical wind models at $90 \mathrm{~km}$ is also shown in Fig. 13. (The method of the GEWM-III construction is the same as that described
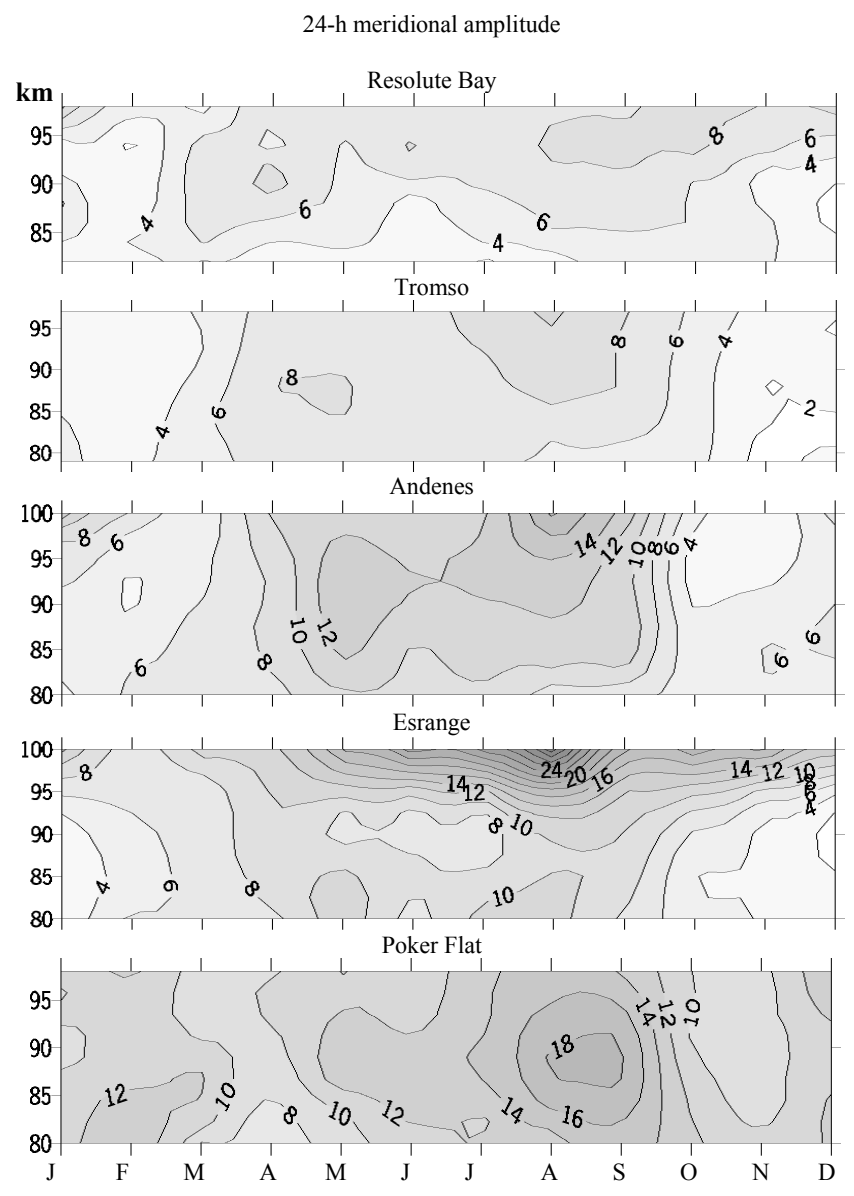

Fig. 12. As Fig. 11, but for monthly mean amplitudes of DT, meridional component.

in Portnyagin et al. (1998) and the database is the same as that described in Portnyagin et al., 2004.) It is interesting to see from this figure that for the high $\mathrm{NH}$ latitudes the experimental data and both empirical models are in a rather good agreement; while for the middle latitudes HWM-93 predicts systematically smaller amplitudes and quite different seasonal behaviour of the phases from the experimental data.

The estimated zonal mean vertical wavelength $\lambda_{z}$ for the diurnal tide is increased toward the Pole. For example, for the summer season $\lambda_{z}=40 \mathrm{~km}$ (zonal comp.) for midlatitudes (near $40^{\circ} \mathrm{N}$ ) and $\lambda_{z}=120 \mathrm{~km}$ for high latitudes; the corresponding values for the meridional component are: $\lambda_{z}=100 \mathrm{~km}$ and $\lambda_{z}>500 \mathrm{~km}$. The tendency to the larger 24-h tide amplitudes at the high latitudes in comparison with that for the mid-latitude belt can also be seen, thus hinting at the possible increasing role of the first anti-symmetric evanescent mode of the diurnal tide.(cf. Longuet-Higgins 1968). This result is confirmed by our estimations of the vertical wavelengths of the diurnal tide for mid- and high latitudes. The longitudinal dependence of the phases of the 24-h oscillation for the solstice and equinoctial months is shown in Fig. 14. Notwithstanding a rather large spread of the individual data, the general longitudinal dependence of the phases is 
lat $=65-75 \mathrm{~N}$

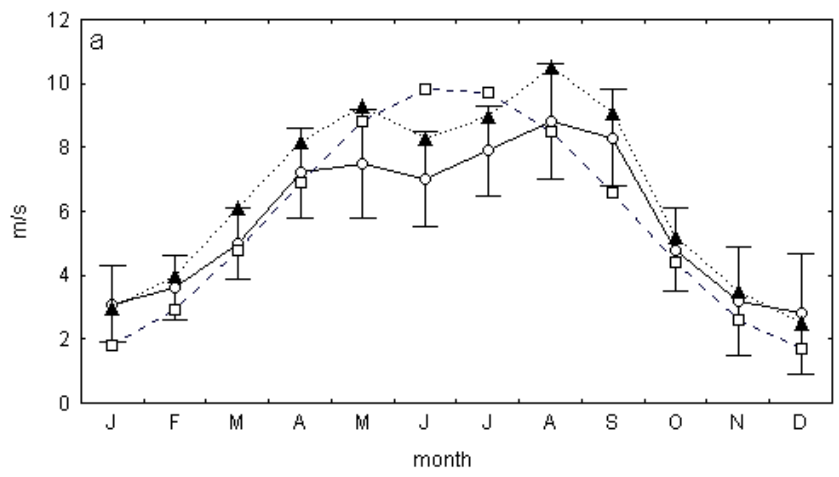

lat $=52-56 \mathrm{~N}$

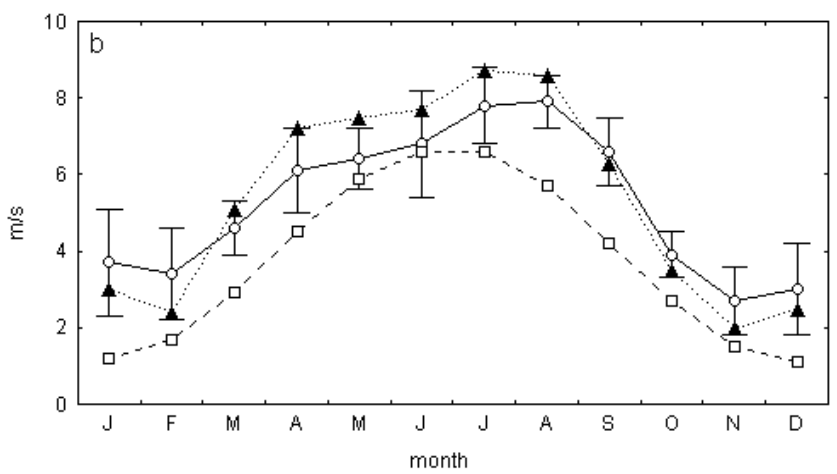

lat $=65-75 \mathrm{~N}$
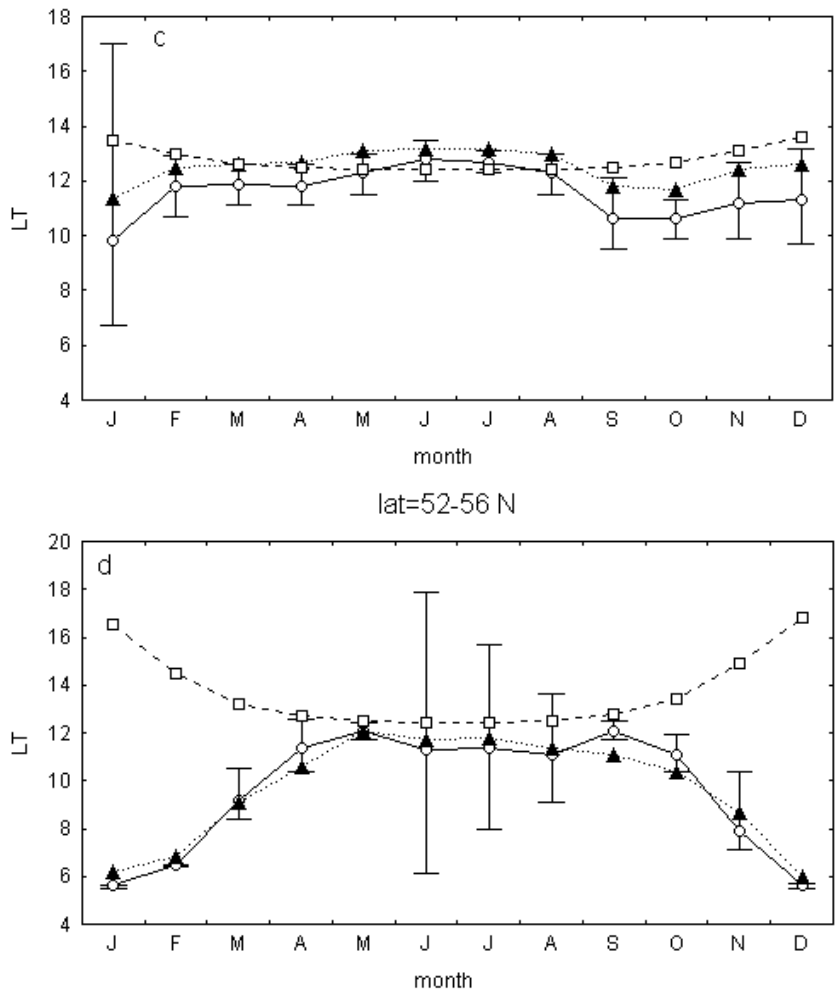

Fig. 13. The zonally averaged seasonal course of the diurnal tide at $90 \mathrm{~km}$; the error bars correspond to the r.m.s. errors for vector averaged values: (a),(b) - amplitude of meridional component, (c),(d)-phase of maximum of meridional component. -o- experimental data, -HWM-93,... $\Delta$...GEWM-III

very definite: the phase of the meridional component is less than that for the zonal component on average at about $6 \mathrm{~h}$ (but not exactly), thus corresponding to the clockwise wind vector rotation; a linear least-square approximation of the phase dependence on longitude makes it possible to estimate the zonal wave numbers of this oscillations. These values for all months of the year are assembled in the Table 3. From this table we may see that the zonal wave numbers are changing from about 0.6 to 1.2 with average values near to $s=1$. The November case is a clear exception and possibly presents the case with the largest inputs of non-migrating tidal components. For this month a difference between phases of the zonal components in LT for the east and west hemispheres is about $12 \mathrm{~h}$.

\section{Conclusion}

The existing network of ground-based MF and meteor radars (MR) for measuring winds in the Arctic upper mesosphere and lower thermosphere provides an excellent opportunity for studies of the main global dynamical structures in this height region. Despite some uncertainty arising from the use of different types of radars it is possible to demonstrate the main common features of the measurements. It is revealed that most of these structures are persistent from year to year and observed at all stations, thus permitting analysis of Arctic
Table 3. Phase of 24-h oscillation (LT).

\begin{tabular}{lcc}
\hline Month & Zonal comp. & Merid. Comp. \\
\hline January & $0.78 \pm 0.15$ & $1.05 \pm 0.21$ \\
February & $0.60 \pm 0.11$ & $0.96 \pm 0.21$ \\
March & $1.15 \pm 0.13$ & $1.18 \pm 0.21$ \\
April & $1.03 \pm 0.13$ & $1.17 \pm 0.21$ \\
May & $0.92 \pm 0.08$ & $1.17 \pm 0.21$ \\
June & $0.70 \pm 0.18$ & $1.27 \pm 0.21$ \\
July & $0.88 \pm 0.18$ & $1.05 \pm 0.19$ \\
August & $0.81 \pm 0.15$ & $1.17 \pm 0.22$ \\
September & $0.79 \pm 0.15$ & $1.14 \pm 0.18$ \\
October & $0.79 \pm 0.18$ & $1.08 \pm 0.22$ \\
November & $0.12 \pm 0.32$ & $0.90 \pm 0.27$ \\
December & $1.17 \pm 0.57$ & $1.30 \pm 0.19$ \\
\hline
\end{tabular}

MLT dynamics in a climatological sense. The seasonal behaviour of the zonally averaged wind parameters, to some extent, is similar to those observed at moderate latitudes. Many features of the revealed seasonal wind variations are different from expectations according to the CIRA-86 and HWM-93 empirical models. In general, the strength of winds in the 
24-h phase, January, $h=88 \mathrm{~km}$

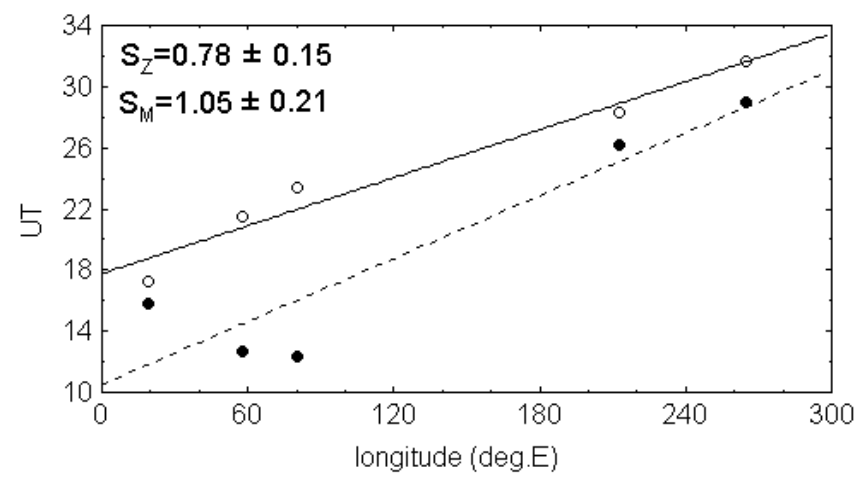

24-h phase, July, h=88 km

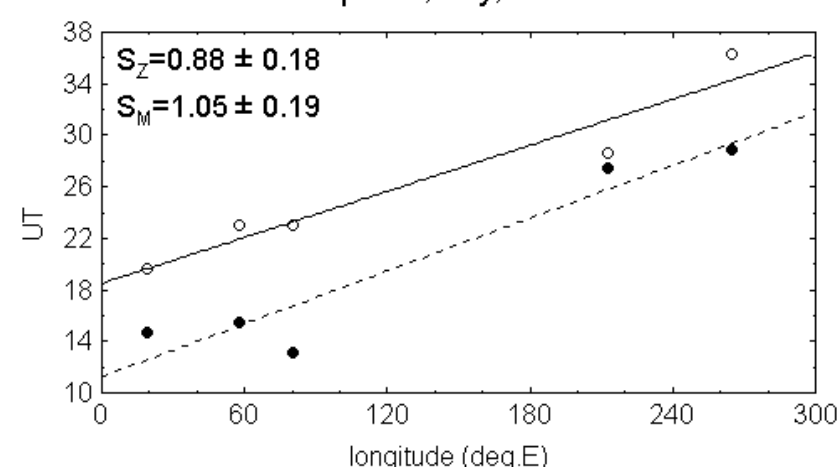

24-h phase, April, h=88 km

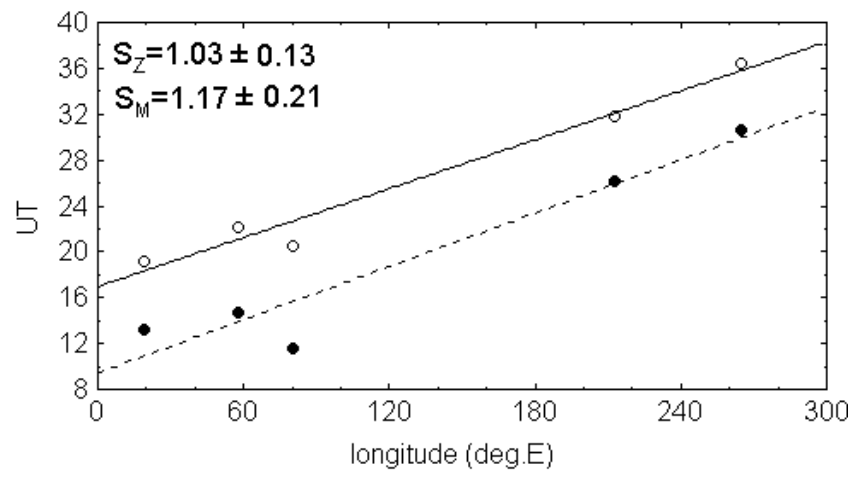

24-h phase, October, h=88 km

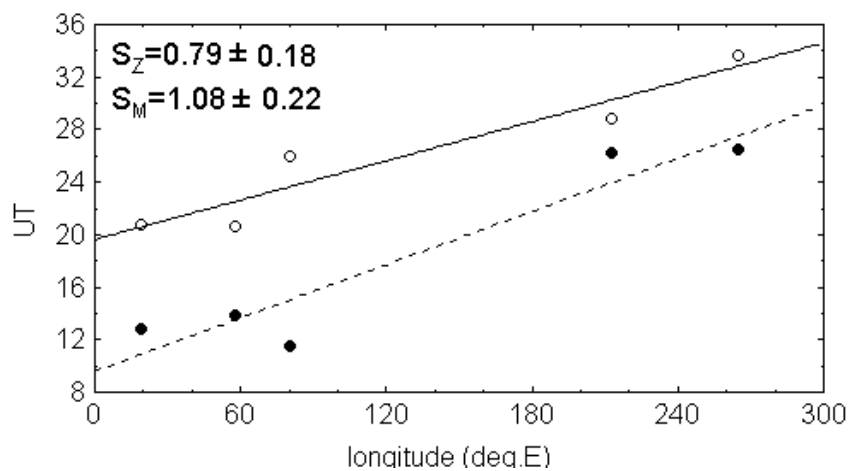

Fig. 14. Dependence of the DT phases (time of maximum in UT) on longitude. $-o-$ zonal component, $-\bullet-$ meridional component.

Arctic MLT region is less than that detected at the moderate latitudes, decreasing toward the pole. However, contrary to the prediction from the HWM-93 model the observed meridional winds do not simply decrease toward the pole.

Regarding the tides, the phases show very definite longitudinal dependence, which permits determination of the corresponding zonal wave numbers. It is shown that the migrating tides play a perhaps dominant role (especially for the 12-h tide) in the dynamics of the Arctic MLT region. However, there are clear indications of the presence, in some months, of non-migrating tides of significant amplitude. The results obtained provide the solid base for constructing comprehensive empirical climatic models of the Arctic MLT dynamics, for analysis of the coupling between the dynamical processes at high and lower latitudes and for understanding their physical mechanisms. It is also obvious that measurements from a more extended network of radar stations with more equipment are needed for further progress in this field as well. Satellite measurements are also needed in the same spatial region.

It would also be of great interest to compare the zonal mean climatology of the Arctic and Antarctic MLT dynamics and to analyse the inter-hemispheric differences in the longitudinal structure of the main high-latitude dynamical processes. The results presented show that to implement this program the comparison has to be made on the basis of an analysis of simultaneous measurements obtained at Arctic and Antarctic radar stations, well distributed over longitude, and within narrow latitudinal belts. Supporting satellite observations are also needed. This work is now in prospect.

Acknowledgements. The work of Russian co-authors was supported by the RFBR grant N 01-05-64238. The Canadian authors are supported by the Natural Sciences and Engineering Research Council. Topical Editor U.-P. Hoppe thanks M. Jarvis and C. Jacobi for their help in evaluating this paper.

\section{References}

Avery, S. K., Vincent, R. A., Phillips, A., Manson, A. H. and Fraser, G. J.: High-latitude tidal behaviour in the mesosphere and lower thermosphere, J. Atmos. Terr. Phys., 51, 595-608, 1989.

Briggs, B. H.: The analysis of spaced sensor records by correlation techniques, Handbook for MAP, 13, 166-186, 1984.

Fauliot, V., Thuillier, G., and Vial, F.: Mean vertical wind in the mesosphere-lower thermosphere region $(80-120 \mathrm{~km})$ deduced from the WINDII observations on board UARS, Ann.Geophysicae, 15, 1221-1231, 1997.

Fleming, E. L., Chandra, S., Shoeberl, M. R., and Barnett, J.,J.: Monthly mean global climatology of temperature, wind, geopotential height and pressure for 0-120 km, NASA Technical Memorandum 100697, 1988.

Forbes, J. M., Makarov, N. A., and Portnyagin, Y.: First results from the meteor radar at South Pole: a large 12-hour oscillation with zonal wavenumber one, Geophys. Res. Lett., 22, 3247 3250, 1995. 
Fraser, G. J., Portnyagin, Y. I., Forbes, J. M., Vincent, R. A., Lysenko, I. A., and Makarov, N. A.: Diurnal tide in the Antarctic and Arctic mesosphere/lower thermosphere regions, J. Atmos. Terr. Phys., 57, 383-393, 1995.

Hall, C.M.: The Ramfjordmoen MF radar $\left(69^{\circ} \mathrm{N}, 19^{\circ} \mathrm{E}\right)$ : application development 1990-2000, J. Atmos. Sol. Terr. Phys., 63,171179, 2001.

Hall, C. M., Aso, T., Manson, A. H., Meek, C. E., Nozawa, S., Tsutsumi, M.: High-latitude mesospheric mean winds: A comparison between Troms $\varnothing\left(69^{\circ} \mathrm{N}\right)$ and Svalbard $\left(78^{\circ} \mathrm{N}\right)$. Journal of Geophysical Research-Atmos.108, D19, 4598, doi:10.1029/ 2003JD003509, 2003.

Hedin, A. E., Fleming, E. L., Manson, A. H., Schmidlin, F. J., Avery, S. K., Clark, R. R., Franke, S. J., Fraser, G. J., Tsuda, T., Vial, F., and Vincent, R. A.: Empirical wind model for the middle and lower atmosphere, J. Atmos. Terr. Phys.,58, 1421-1447, 1996.

Hook, J. L.: Winds at the $75-110 \mathrm{~km}$ level at College, Alaska, Planet. Space Sci., 18, 1623-1638, 1970.

Hocking, W.-K.: Middle atmosphere dynamical studies at Resolute Bay over a full year: mean winds, tides and special oscillations, Radio Sci.,36, 1795-1822, 2001.

Hocking, W. K., Fuller, B., and Vandepeer, B.: Real-time Determination of Meteor-related Parameters Utilizing Modern Digital Technology, J. Atmos. Solar-Terr. Physics, 63, 155-169, 2001 a.

Hocking, W. K., Kelley, M. C., Rogers, R., Brown, W. O. J., Moorcroft, D., and Maurice, J.-P. St.: Resolute Bay VHF radar: A multi-purpose tool for studies of tropospheric motions, middle atmosphere dynamics, meteor physics and ionospheric physics, Radio Sci., 36, 1839-1857, 2001b.

Hocking, W. K.: Strengths and limitations for MST radar measurements of middle atmosphere winds, Annales Geophys., 15,11111122, 1997.

Hocking, W. K. and Thayaparan, T.: Simultaneous and co-located observations of winds and tides by $\mathrm{MF}$ and meteor radar over London, Canada $\left(43^{\circ} \mathrm{N}, 81^{\circ} \mathrm{W}\right)$ during 1994-1996, Radio Sci.,32(2),833-865, 1997.

Iljichev, Yu. D., Lysenko, I. A., Orlyansky, A. D., and Portnyagin, Y. I.:Space and time variations of large-scale motions in the lower thermosphere, J. Atmos. Terr. Phys.,36, 1841-1849, 1974.

Jacobi, Ch., Portnyagin, Y. I., Solovjova, T. V., Hoffmann, P., Songer, W., Fahrutdinova, A. N., Ishmuratov, R. A., Beard, A. G., Mitchell, N. J., Muller, H. G., Schminder, R., Kürschner, D., Manson, A. H., Meek C. E.: Climatology of the semidiurnal tide at $52-56^{\circ} \mathrm{N}$ from ground-based radar wind measurements $1985-$ 1995, J. Solar Terr. Phys.,61,975-991, 1999.

Kishore, P., Namboothiri, S. P., Igarashi, K., Murayama, Y., and Watkins, J.: MF radar observations of mean winds and tides over Poker Flat, Alaska ( $\left.65.1^{\circ} \mathrm{N}, 147.5^{\circ} \mathrm{W}\right)$, Ann. Geophys., 20, 679690, 2002

Kishore, P., Namboothiri, S. P., Igarashi, K., Murayama, Y., Vincent, R. A., Dowdy, A., Murphy, D. J., Watkins, B. J.: Further evidence of hemispheric differences in the MLT mean wind climatology: simultaneous $\mathrm{MF}$ radar observations at Poker Flat ( $\left.65^{\circ} \mathrm{N}, 147^{\circ} \mathrm{W}\right)$ and Davis $\left(69^{\circ} \mathrm{S}, 78^{\circ} \mathrm{E}\right)$, Geophys. Res. Lett.,30(6),10.1029/2002GL016750, 2003.

Longuet-Higgins M. S.: The eigenfunctions of Laplace's tidal equations over a sphere, Phill. Trans. Roy. Soc., A262,511-607, 1968.

Lysenko, I. A., Kascheev, B. L., Karimov, K. A., Nazarenko, M. K., Orlyansky, A. D., Fialko, E. I., Chebotarev, R. P.: Results of studies of atmospheric circulation over the Eurasia and the
Arctic by the meteor radar method, Proceed. Acad. Sci. USSR, ser. "Physics of Atmosphere and Ocean",( in Russian), 5,No.9, 893-902, 1969.

Lysenko, I. A., Orlyansky, A. D., and Portnyagin, Y. I.: A study of the wind regime at an altitude of about $100 \mathrm{~km}$ by the meteor radar method,Phil. Trans. R. Soc. Lond.,A271, 601-610, 1972.

Lysenko, I. A., Orlyansky, A. D., Portnyagin, Y. I.: Results of wind's velocities measurements at middle and high latitudes by the meteor radar method, J. Geomagn. Geoelectr., 31, 411-418, 1979.

Manson A. H., Meek, C. E., Hall, C. M., Nozawa, S., Mitchell, N. J., Pancheva, D., Singer, W., and Hoffmann, P.: Mesopause dynamics from the Scandinavian triangle of radars within the PSMOSDATAR project, Annales Geophysicae,22,367-386, 2004a.

Manson, A. H., Meek, C. E., Hagan, M., Zhang, X., and Luo, Y.: Global distributions of diurnal and semi-diurnal tides: Observations from HRDI-UARS of the MLT Region and Comparisons with GSWM-02 (Migrating, Non-migrating Components). Ann. Geophys., 22, 1529-1548, 2004b.

Manson A. H., Meek, C., Hagan, M., Koshyk, J., Franke, S., Fritts, D., Hall, C., Hocking, W., Igarashi, K., MacDougall, J., Riggin, D., and VincentSeasonal, R.: Variations of the semi-diurnal and diurnal tides in the MLT: multi-year MF radar observations from 2-70 ${ }^{\circ} \mathrm{N}$, modelled tides (GSWM, CMAM). Ann. Geophys., 20, 661-677, 2002a.

Manson A. H., Luo, Y., and Meek, C.: Global Distributions of Diurnal and Semi-Diurnal Tides: Observations from HRDI-UARS of the MLT Region. Ann. Geophys.,20, 1877-1890, 2002b.

Manson A. H. and Meek C. E: Climatologies of mean winds and tides observed by medium frequency radars at Troms $\varnothing\left(70^{\circ} \mathrm{N}\right)$ and Saskatoon $\left(52^{\circ} \mathrm{N}\right)$ during 1987-1989, Can. J. Phys.,. 69, 966-975, 1991.

Manson A. H., Meek, C. E., Massebeuf, M., Fellous, J.-L., Elford, W. G., Vincent, R. A., Craig, R. L., Roper, R. G., Avery, S., Balsley, B. B., Fraser, G. J., Smith, M. J., Clark, R. R., Kato, S., Tsuda, T., and Ebel, A.: Mean winds of the upper middle atmosphere $(60-110 \mathrm{~km})$ : a global distribution from radar systems (MF, meteor VHF),Handbook for MAP, 16, 239-268, 1985.

Manson A. H., Meek, C. E., Massebeuf, M., Fellous, J.-L., Elford, W. G., Vincent, R. A., Craig, R. L., Roper, R. G., Avery, S., Balsley, B. B., Fraser, G. J., Smith, M. J., Clark, R. R., Kato, S., Tsuda, T.: Mean winds of the upper middle atmosphere ( $70-110 \mathrm{~km}$ ) from the global radar network: comparison with CIRA-72, and new rocket and satellite data,Adv. Space Res., 7,N.10,143-153, 1987.

Massebeuf, M., Bernard, R., Fellous, J. L., and Glass, M.: The mean zonal circulation in the meteor region above Garchy (France) and Kiruna ( Sweden), J. Atmos. Terr. Phys., 41,647-655, 1979.

Meek, C. E.: An efficient method for analysing ionospheric drifts data. J. Atmos. Terr. Phys., 42,835-839, 1980.

Merzlyakov, E. G., Portnyagin, Yu. I., Makarov, N. A., Forbes, J. M., and Palo, S.: First results of meteor radar lower thermosphere wind measurements at Dixon, Arctic $\left(73.5^{\circ} \mathrm{N}, 80^{\circ} \mathrm{E}\right)$, Adv. Polar Atmos. Res., No. 15, 11-22, 2001.

Merzlyakov, E. G., Portnyagin, Y. I., Makarov, N. A., Forbes, J. M., and Palo, S.: Some results of simultaneous meteor radar measurements of wind at the Obninsk and Dixon stations, Izvestiya of the Russian Academy of Sci., ser. Atmospheric and Oceanic Physics, 39, 36-45, 2003.

Mitchell N. J., Pancheva, D., Middleton, H. R., and Hagan, M.: Mean winds and tides in the Arctic mesosphere and lower thermosphere, J. Geophys. Res.,107, A1.P.SIA 2-1 - SIA 2-14, 2002. 
Murayama, Y., Igarashi, K., Rice, D., Watkins, B., Collins, R., Mizutani, K., Saito, Y., and Kainuma, S.: Medium Frequency Radars in Japan and Alaska, for Upper Atmosphere Observations, IEICE Trans., E83-B, 1996-2003, 2000.

Murphy, D.: Variations in the phase of the semidiurnal tide over Davis, Antarctica, J. Atmos. Solar-Terr. Phys., 64, 1069-1081, 2002.

Portnyagin, Y. I., Forbes, J. M., Fraser, G. J., Vincent, R. A., Lysenko I. A., and Makarov, N. A.: Dynamics of the Antarctic and Arctic mesosphere and lower thermosphere regions-I. The prevailing wind, J. Atmos. Terr. Phys.,55,827-841, 1993a.

Portnyagin, Y. I., Forbes, J. M., Fraser, G. J., Vincent, R. A., Lysenko I. A., and Makarov, N. A.: Dynamics of the Antarctic and Arctic mesosphere and lower thermosphere regions-II. The semidiurnal tide, J. Atmos. Terr. Phys., 55, 843-855, 1993 b.

Portnyagin, Y. I., and Solovjova, T. V.: The role of vertical momentum fluxes in maintaining global meridional circulation in thermosphere/upper mesosphere, J. Atmos. Solar-Terr. Phys., 59, 511-525, 1997.

Portnyagin, Y. I. Solovjova, T. V.: Empirical semidiurnal migrating tide model for the upper mesosphere/lower thermosphere, Adv. Space Res., 21, N6,811-815, 1998.
Portnyagin, Y, I. and Solovjova, T. V.: Global empirical wind model for the upper mesosphere/lower thermosphere,Ann. Geophysicae, 18, 300-315, 2000.

Portnyagin,Y. I., Solovjova, T., Merzlyakov, E., Forbes, J., Palo, S., Ortland, D., Hocking, W., MacDougall, J., Thayaparan, T., Manson, A., Meek, C., Hoffmann, P., Singer, W., Mitchell, N., Pancheva, D., Igarashi, K., Murayama, Y., Jacobi, C., Kuerschner, D., Fahrutdinova, A., Korotyshkin, D., Clark, R., Tailor, M., Franke, S., Fritts, D., Tsuda, T., Nakamura, T., Gurubaran, S., Rajaram, R., Vincent, R., Kovalam, S., Batista, P., Poole, G., Malinga, S., Fraser, G., Murphy, D., Riggin, D., Aso, T., Tsutsumi, M.: Global empirical wind model for the upper mesosphere/lower thermosphere. Mesosphere/lower thermosphere prevailing wind model, Adv. Space Res., in press, 2004.

Riggin, D. M., Fritts, D. C., Jarvis, M. J., and Jones, G. O. L.: Spatial structure of the 12-hour wave in the Antarctic as observed by radar, Earth, Planets and Space, 51, 621-628, 1999. Riggin, D. M., Meyer, C. K., Fritts, D. C., Jarvis, M. J., Murayama, Y., Singer, W., Vincent, R. A., Murphy, D. J.: MF radar observations of seasonal variability of semidiurnal motions in the mesopshere at high northern and southern latitudes, J. Atmos. Solar-Terr.Phys., 65, 483-493, 2003. 